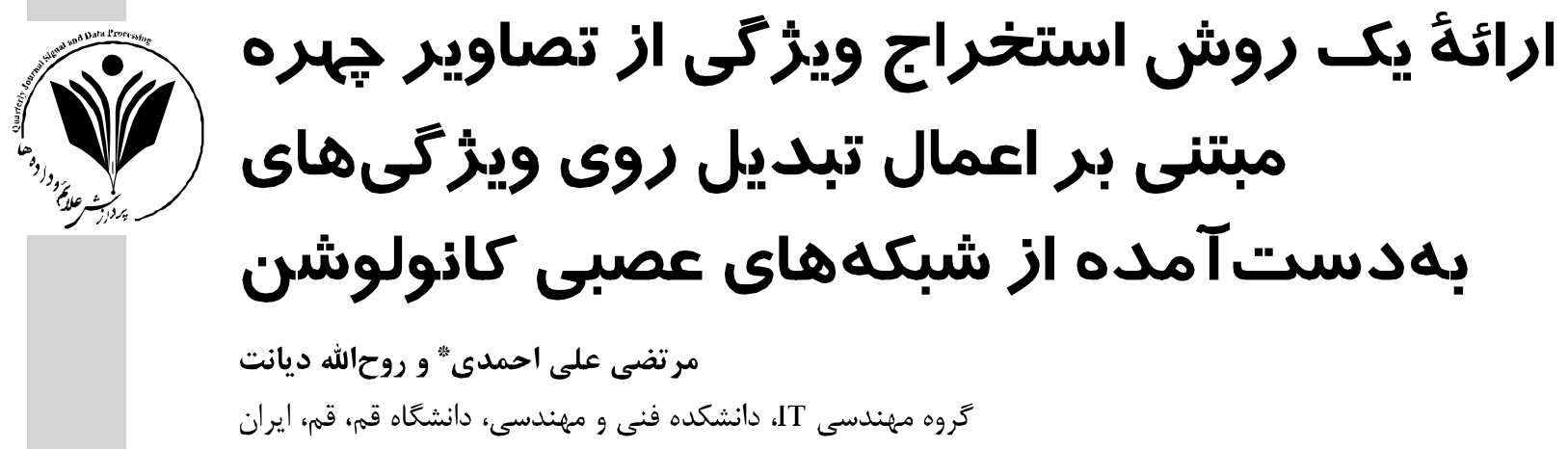

جكبد

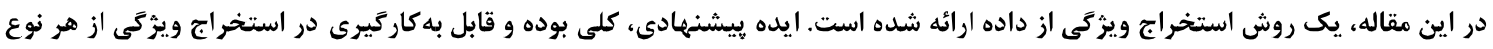

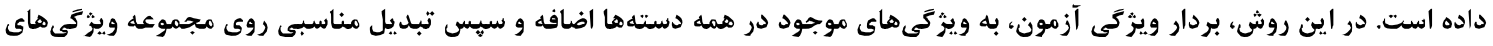

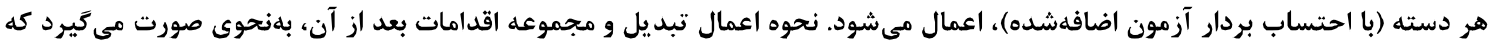

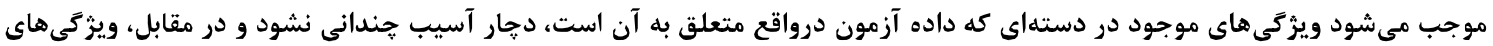

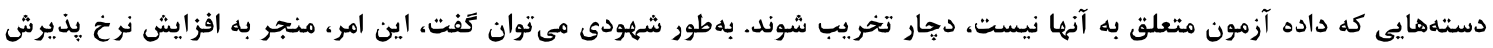

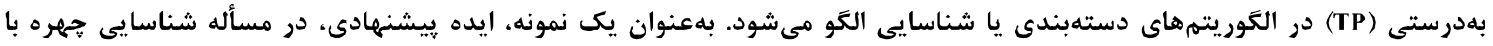

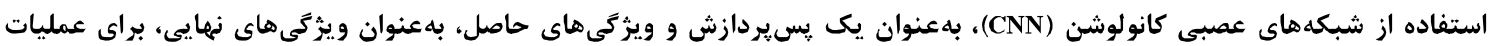

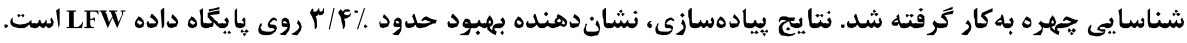

وازَّان كليدى: استخر اج ويزَّى، شبكههاى عصبى كانولوشن، تبديل موجك، تبديل فوريه

\title{
Introducing a method for extracting features from facial images based on applying transformations to features obtained from convolutional neural networks
}

\author{
Morteza ali ahmadi* \& Rouhollah dianat \\ Department of IT Engineering, Faculty of Technical and Engineering, \\ The University of Qom Qom, Iran
}

\begin{abstract}
In pattern recognition, features are denoting some measurable characteristics of an observed phenomenon and feature extraction is the procedure of measuring these characteristics. A set of features can be expressed by a feature vector which is used as the input data of a system. An efficient feature extraction method can improve the performance of a machine learning system such as face recognition in the image field.

Most of the feature extraction methods in facial images are categorized as geometric feature extractor methods, linear transformation-based methods and neural network-based methods. Geometric features include some characteristics of the face such as the distance between the eyes, the height of the nose and the width of the mouth. In the second category, a linear transformation is applied to the original data and displaces them to a new space called feature space. In the third category, the last layer in the network, which is used for categorization, is removed, and the penultimate layer output is used as the extracted features. Convolutional Neural Networks (CNNs) are one the most popular neural networks and are used in recognizing and verifying the face images, and also, extracting features.
\end{abstract}

* Corresponding author

*نويسندة عهدهدار مكاتبات

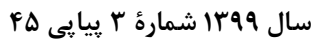

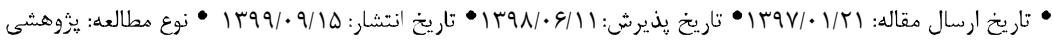


The aim of this paper is to present a new feature extraction method. The idea behind the method can be applied to any feature extraction problem. In the proposed method, the test feature vector is accompanied with the training feature vectors in each class. Afterward, a proper transform is applied on feature vectors of each class (including the added test feature vector) and a specific part of the transformed data is considered. Selection of the transform type and the other processing, such as considering the specific part of the transformed data, is in such a way that the feature vectors in the actual class are encountered with less disturbing than the other ones. To meet this goal, two transformations, Fourier and Wavelet, have been used in the proposed method. In this regard, it is more appropriate to use transformations that concentrate the energy at low frequencies. The proposed idea, intuitively, can lead to improve the true positive (TP) rate.

As a realization, we use the idea in CNN-based face recognition problems as a post-processing step and final features are used in identification. The experimental results show up to $3.4 \%$ improvement over LFW dataset.

Keywords: Feature extraction - Convolutional neural networks - Wavelet transform - Fourier transform.

$$
\begin{aligned}
& \text { بردارهاى Fisher بوده است. اين روشها حتى بدون انجام } \\
& \text { ترازسازى و كام تعيين لندماركىها، كارايى مناسبى دارند. } \\
& \text { در مقاله فعلى، رويكردى جهت استخراج ويزگگى، ارائه } \\
& \text { شده است. ايده بيانشده، عمومى بوده كه بهطور بالقوه روني }
\end{aligned}
$$

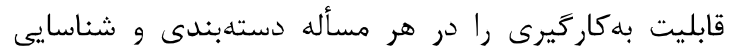

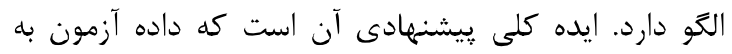

$$
\begin{aligned}
& \text { همه دستههاى موجود در كالرى (افراد)، اضافه شود. در لرد } \\
& \text { ادامه، تبديلى روى دادههاى هر دسته كه اكنون شامل داده }
\end{aligned}
$$

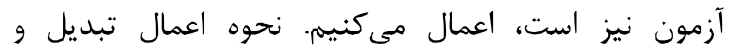

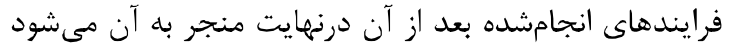

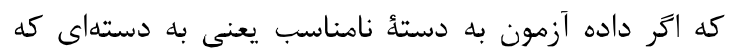

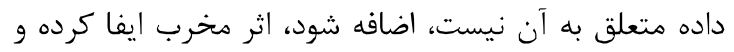

$$
\begin{aligned}
& \text { بدينترتيب، احتمال خطا (يعنى تشخيص نادرست دسته) را } \\
& \text { كمتر مى كند. }
\end{aligned}
$$

در مقابل، افزودن داده آزمون به دسته مناسب، يعنى

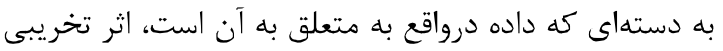

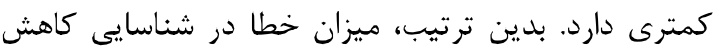

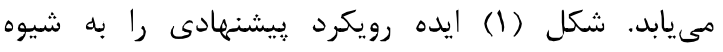

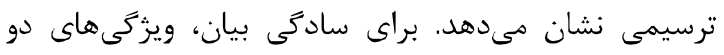

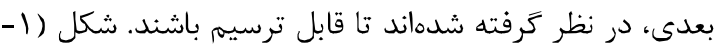

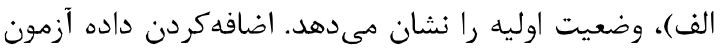
به همه دستهها و اعمال تبديل، منجر مىشود كه دسته كه داده آزمون بهطورواقعى متعلق به آن آنها است، به نمونه

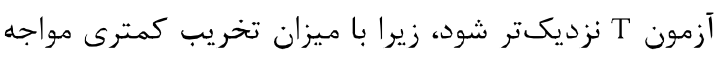
شده است. در مقابل، بقيه دستهها، از نمونه آزمون دورتر

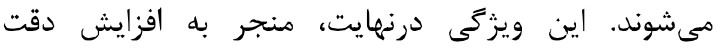
دستهبندى و توليد خطاى كمتر، خواهد شد؛ لذا انتظار داريم استفاده از اين روش، منجر به بهبود يارامتر

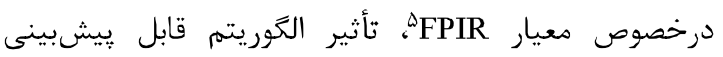

${ }^{4}$ True positive identification rate (TPIR)

${ }^{5}$ False positive identification rate (FPIR)

$$
\begin{aligned}
& \text { - } \\
& \text { شناسايى جهره'، يكى از مهمثرين مباحث مطرح در حوزه }
\end{aligned}
$$

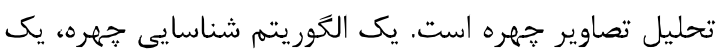

$$
\begin{aligned}
& \text { تصوير جهره را بهعنوان ورودى دريافت و تعلق يا عدم تعلق } \\
& \text { تصوير به افراد موجود را در يك كالرى، تعيين مى كند. } \\
& \text { مهمترين قسمت يك الخوريتم شناسايى جهره، مرحله } \\
& \text { استخراج ويزگى است. ايده در نظر كرفتهشده مي بايست } \\
& \text { باصورتى باشد كه منجر به توليد ويزكى هاى باشد كه نسبت } \\
& \text { به موانعى هون تغيير وضعيت يا حالت جهره، سن، شرايط } \\
& \text { نورى مختلف و ....، مقاوم شود. الخوريتهمهاى فراوانى براى } \\
& \text { استخراج ويثزى از تصوير جهره ارائه شدهاند كه در بخش r. } \\
& \text { مهرترين آنها مرور خواهند شد. يك دسته از رويكردهايى كد } \\
& \text { در سالهاى اخير مورد توجه بوده و دقتهاى بالايى در } \\
& \text { استفاده از آنها در حوزههاى مختلف شناسايى الكو، كزارش } \\
& \text { شده، روشهاى مبتنى بر شبكههاى عصبى عميق است. در } \\
& \text { حوزه شناسايى ههره، روشهاى مبتنى بر شبكه عصبى } \\
& \text { كانولوشن (CNN) } \\
& \text { عمل شناسايى را انجام مىدهند. بهعنوان نمونه مىتوان } \\
& \text { نتايج مسابقات ILSVRC را راد كرد كه در آن، دقت } \\
& \text { الكوريتمهاى دستهبندى مختلف روى مجموعه داده }
\end{aligned}
$$

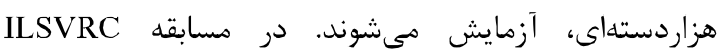

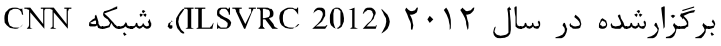
ييشنهادشده توسط كريزفسكى و ديخران، به خطاى

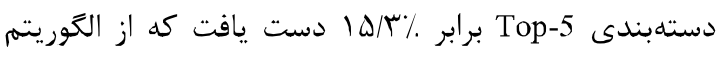
رتبه دوم اين مسابقه \% 19 • بهيتر بود [1]. كفتنى است كه الكوريتم رتبه دوم، سنتى بوده و مبتنى بر الكوريتهم SIFT و

${ }^{1}$ Face recognition

${ }^{2}$ Convolutional neural network (CNN)

${ }^{r}$ ImageNet large scale visual recognition challenge (ILSVRC) 
آنكه در بخش بيادهسازى، الخوريتم بيشنههادى روى رويكرد

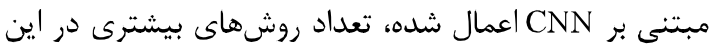
حوزه، مورد بررسى قرار كرفته است. در يك نخاه كلى، اغلب روشهاى معروف استخراج ويزگ

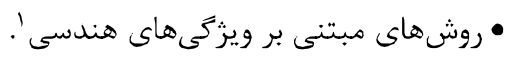

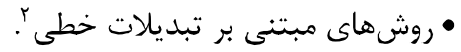

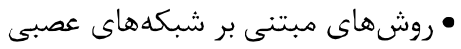

\section{ا-r- روش هاى مبتنى بر استخراج ويرَّى هاى

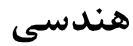

در اغلب روشهاى اوليه استخراج ويزگى از تصاوير جههره،

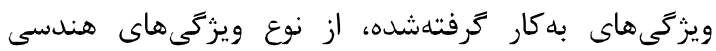
بودهاند. منظور از ويزگى هاى هندسى، مواردى نظير فاصله

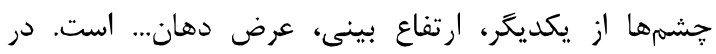
جدول (1) براى نمونه، سه روش از اين دسته، مرور شده يده

(جدول -1): جند روش هندسى استخراج ويزگى تصاوير جهره (Table-1): Some geometrical face feature extraction methods

\begin{tabular}{|c|c|}
\hline يحات & روش \\
\hline 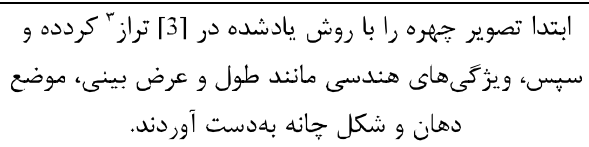 & بوتيو [2] \\
\hline 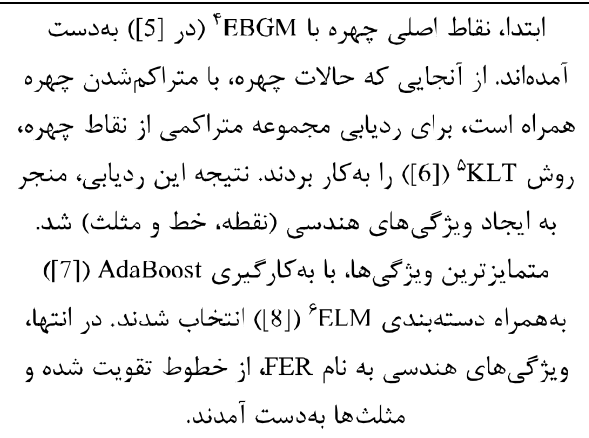 & هيمير و هماران \\
\hline 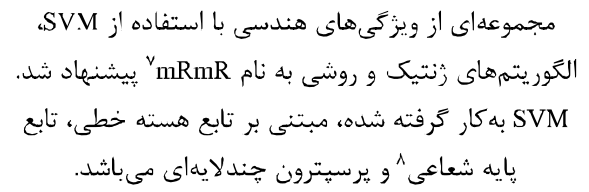 & 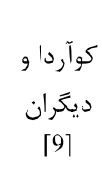 \\
\hline
\end{tabular}

${ }^{1}$ Geometric features

${ }^{2}$ Lincar transformations

${ }^{3}$ Align

${ }^{4}$ Elastic bunch graph matching (EBGM)

${ }^{5}$ Kanade-Lucas-Tomaci (KLT)

${ }^{6}$ Extreme learning machine (ELM)

${ }^{7}$ Minimum redundancy maximum relevance ( $\mathrm{mRmR}$ )

${ }^{8}$ Radial basis function
نيست؛ جون، تصوير آزمون، متعلق به هيج يك از افراد

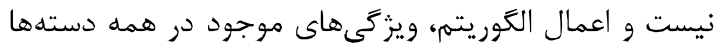

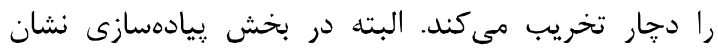

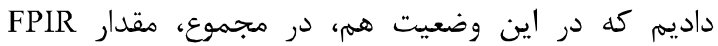
مناسبى به دست آمده است (تعريف و توضيح اين دو يارامتر در بخش r-f أ بيان خواهد شد).

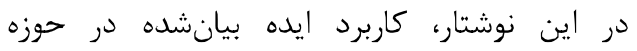
شناسايى جهره بيان شده و همجنين، فرض شده است كه

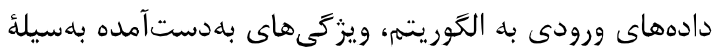
يك CNN باشد. ساختار ارائهده در ادامه بلشرح زير است: با توجه به

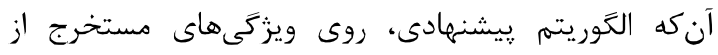

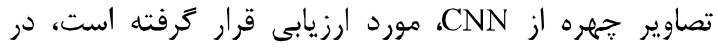
بخش r ז، مرور كلى بر روشهاى استخراج ويزگى از تصاوير

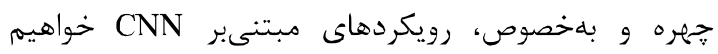

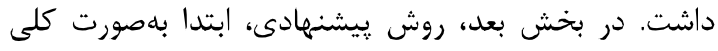

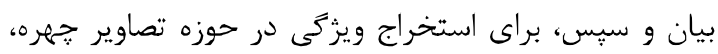
سفارشى شده است. بخش عأ بل بررسى و تحليل نتايج

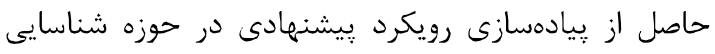

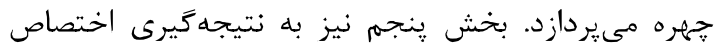
دارد.

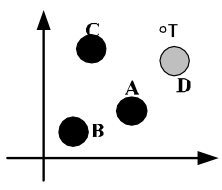

(ب)

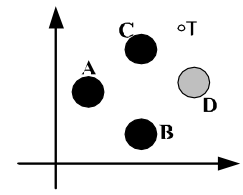

(الف)

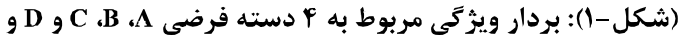

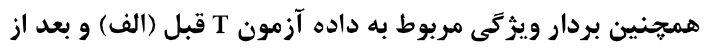

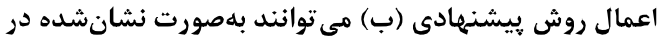

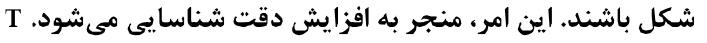

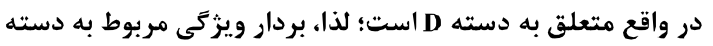
D با رنغ ديخرى نشان داده شده است.

(Figure-1): Feature vectors of 4 hypothetical class A, B, $C$ and $D$ accompanying test feature vector $T$

I) before and II) after applying the proposed method can be as showed in figure. This leads to increased accuracy of identification. Since, $T$ actually belongs to the class $D$, so the feature vector of the class $D$ is shown in a different color.

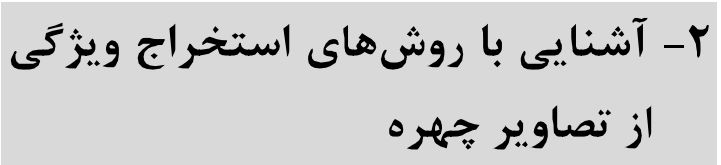

در اين قسمت، روشهاى مختلف استخراج ويزّىى از تصاوير جهره بهصورت كلى مورد بررسى قرار مى گيرند. با توجه به له 
بيانشده در حوزه استخراج ويثگى از تصاوير جهره، آهده

يكى از كاربردهاى مهرم شبكههاى عصبى، استخراج

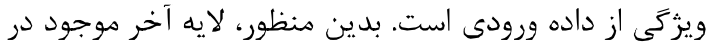

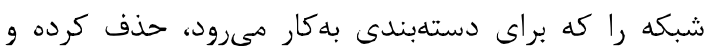

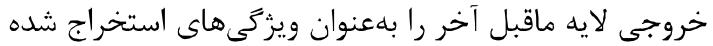

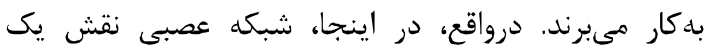

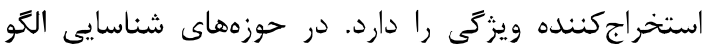
مانند شناسايى جهره، بهطورمعمول شبكه عصبى به ركار

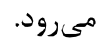

(جدول-ץ): روش هاى استخراج ويزّى مبتنى بر شبكههاى عصبى عميق ايتحري

(Table-3): Deep neural network-based feature extraction methods

\begin{tabular}{|c|c|}
\hline توضيحات & نام روش \\
\hline 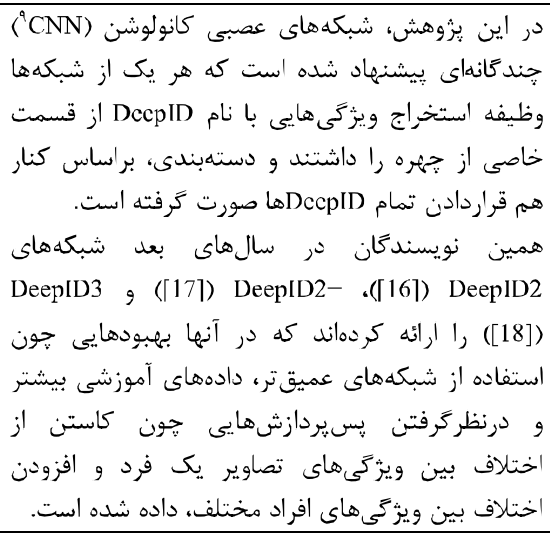 & $\begin{array}{c}\text { DeepD } \\
{[15]}\end{array}$ \\
\hline 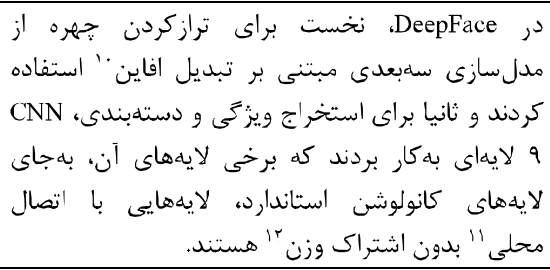 & $\begin{array}{c}\text { DeepFace } \\
{[19]}\end{array}$ \\
\hline 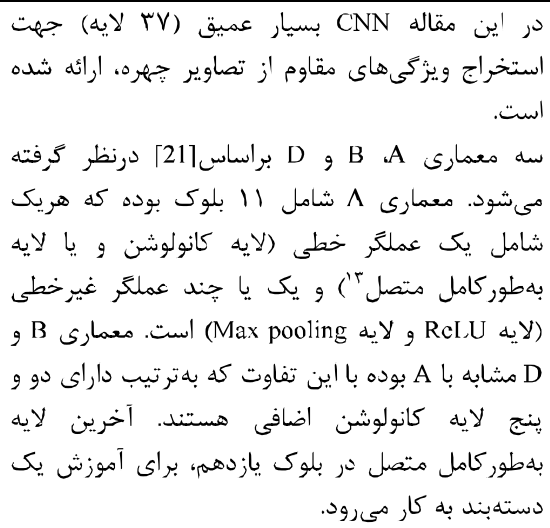 & $\begin{array}{c}\text { VGGFace } \\
{[20]}\end{array}$ \\
\hline
\end{tabular}

${ }^{9}$ Convolutional neural network (CNN).

${ }^{10}$ Affine transformation

${ }^{11}$ Locally connected layers

${ }^{12}$ Weight sharing

${ }^{13}$ Fully connected
T-Y- روشهاى استخراج ويرَى مبتنىبر

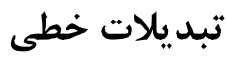

مبناى كلى اين دسته، اعمال يك تبديل خطى روى دادهایى داى

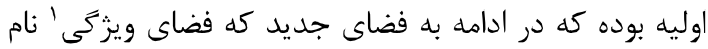

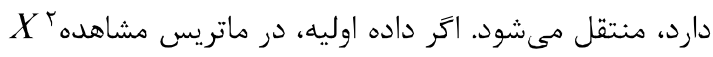
قرار داشته باشد، به ماتريس مشاهده جديد

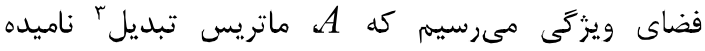
مىشود. تفاوت بين رويكردها، ناشى از تفائر

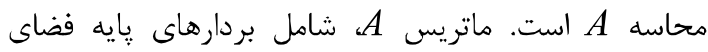

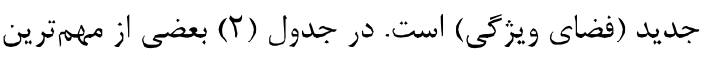

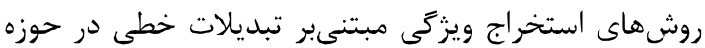
تصاوير حهره، آورده شدهاند.

(جدول - (Y): جند روش استخراج ويرَتى مبتنى بر تبديلات خطى (Table-2): Some linear transform-based feature extraction methods

\begin{tabular}{|c|c|}
\hline توضيحات & نام روش \\
\hline 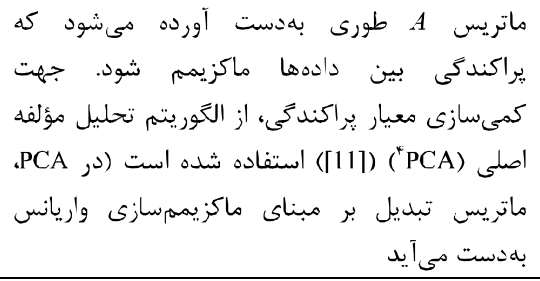 & $\begin{array}{c}\text { EigenFace } \\
{[10]}\end{array}$ \\
\hline 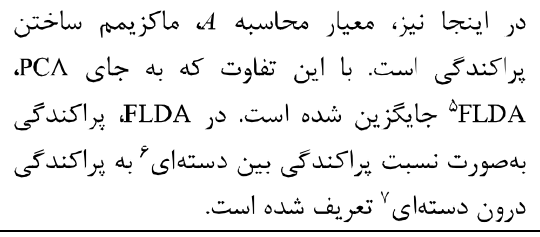 & $\begin{array}{c}\text { FisherFace } \\
{[12]}\end{array}$ \\
\hline 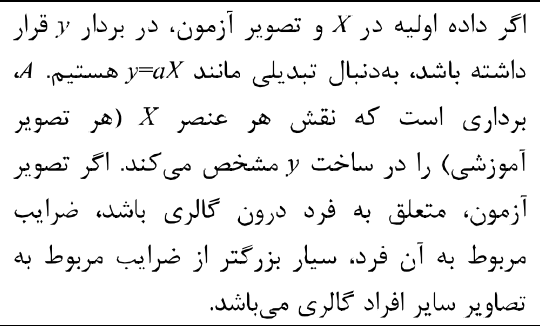 & نمايش تنكى] \\
\hline
\end{tabular}

\section{r-r - - روش هاى مبتنى بر شبكههاى عصبى}

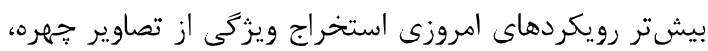
از شبكدهاى عصبى و بهخصوص، شبكدهاى عصبى عميق،

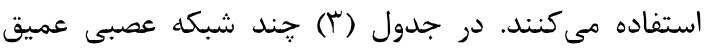

${ }^{1}$ Feature space

${ }^{2}$ Observation matrix

${ }^{3}$ Transformation matrix

${ }^{4}$ Principal component analysis (PCA)

${ }^{5}$ Fisher lincar discriminant analysis (FLDA)

${ }^{6}$ Between-class scatter

${ }^{7}$ Within-class scatter

${ }^{8}$ Sparse representation 
ساير دستهها مىشود (جزئيات بيشتر در بخش

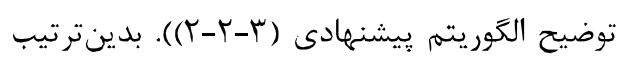

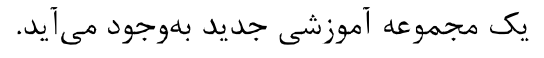

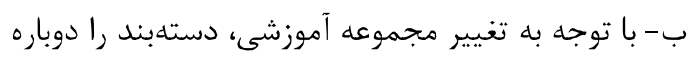
با داده آموزشى جديد، آموزش بده.

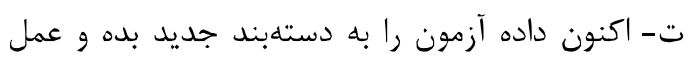

$$
\text { دستهبندى را روى آن انجام بده. }
$$

نكته: درصورتى كه براى دستهبندى، از معيارهاى فاصله يا لنام بده انطباق استفاده شود، مراحل ب و ت بلهصورت زير انجام

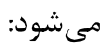

ب-فاصله داده آزمون را با داده نماينده هر دسته به

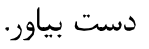

ت- داده آزمون را به دستهاى منسوب كن كد كمترين فاصله را با آن دسته داشته باشد.

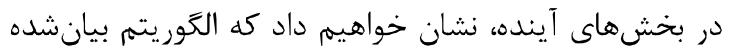
توانسته اين ايده را محقق سازد.

r-r- بيان الكوريته ارائهشده و توضيحاتى درخصوص بعضى مراحل آن

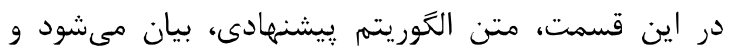

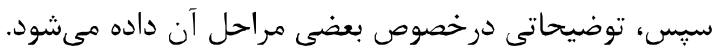

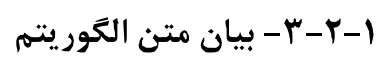

ورودى: الكوريتم داراى دو دسته ورودى بهشرح زير است.

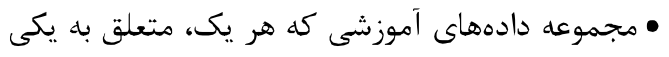
از C دسته هستند. فرض مى كنيم دسته أام، داراى n نمونه باشد. هر نمونه، $d$ بعدى در نظر كرفتئه مىشود. بدينترتيب، بهازاى هر دسته iام، بعدى خواهيم داشت. • داده آزمون كه طبيعتاً آن هم d بعدى است و آن آن را با م نمايش مى دهيه. الف- داده آزمون را به هر يك إنمئ از دستهها اضافه كن. اكنون دسته iام،

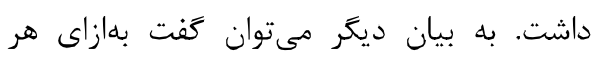

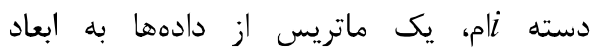

$$
\text { خواهيم داشت. }
$$

ب- اكنون بهازاى هر دسته أام كارهاى زير را انجام بده

\section{r- توضيح روش پييشنهادى}

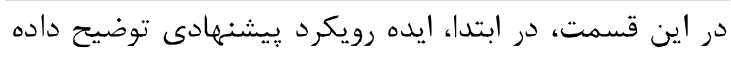

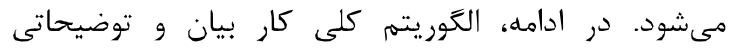

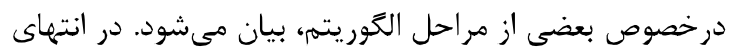
اين بخش، الكوريته كلى بيانشده در كاربرد شناسايى جهره،

$$
\text { سفارشى مىشود. }
$$

\section{ا-r- توضيح ايده روش بيشننهادى}

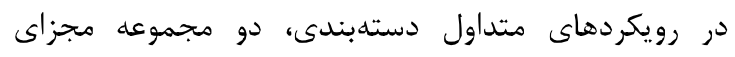

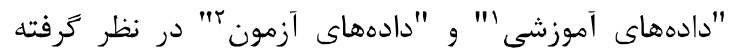

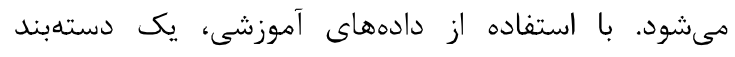
ساخته و سيس، از دستهبند براى دستهبندى دادههاى آز آزمون

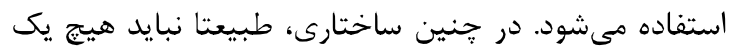
از دادههاى آزمون در مجموعه دادههاى آموزشى وجنى وجود

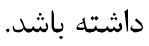
در اين مقاله، به مسأله بيانشده در بالا، از جنبه

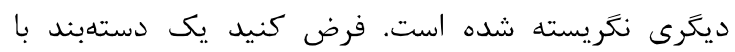

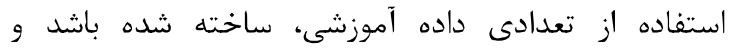

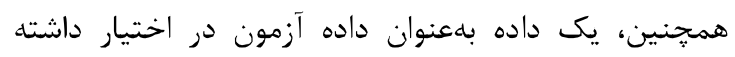
باشيه.

ايدهاى كه مبناى روش بيشنهادى است آن است كه

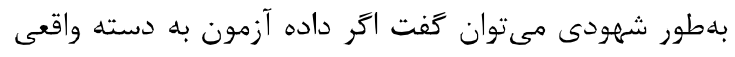

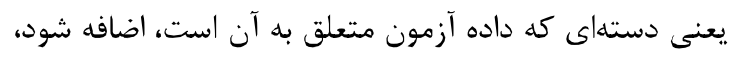

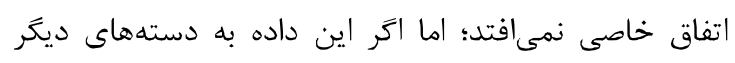

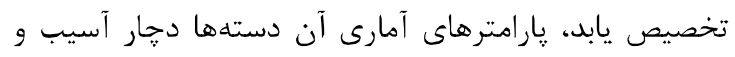

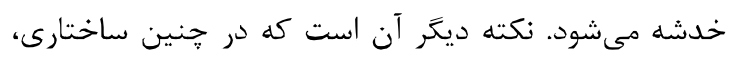

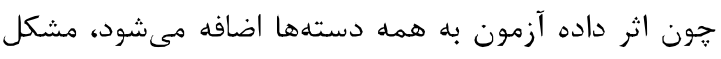

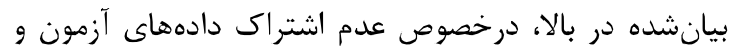
آموزشى پيش نمى آيد. بهمنظور عملىتركردن اين ايده، مراحل كلى زير

$$
\text { ييشنهاد مى شود: }
$$

الف- داده آزمون را به همه دستهها اضافه كن و سيس،

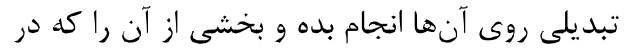

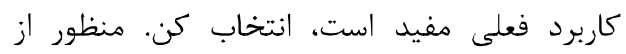

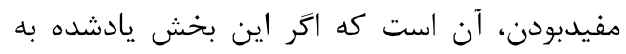

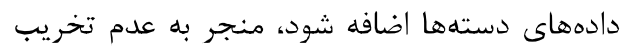

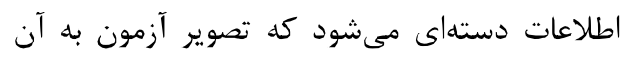
متعلق است و در مقابل، موجب تخريب اطلاعات

${ }^{1}$ Training data
${ }^{2}$ Test data 
نتايج بيادهازىهاى انجامشده، رضايتبخش بوده

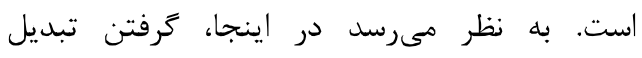
معكوس، هر جند راهكار ايدهآل و اصلى نيست، اما تا لت

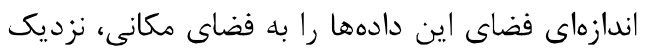
مى كند. براى مثال، در تبديل فوريه جون محاسئ دهاسيه معكوس بر مبناى توانهاى نمايى با علامت مثبت،

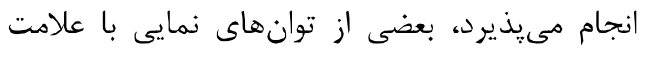

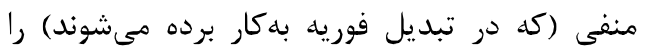
خنثى مى كند. ب-ه- اكنون، دادهاى را كه در قسمت الف به دسته اضافه

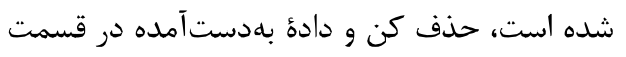
بداراى (1) بماى

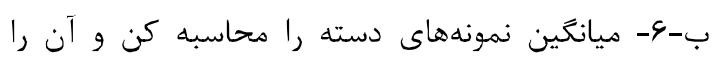

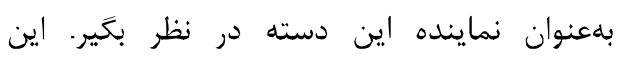

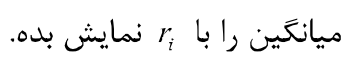

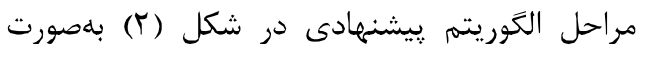
شبه كد نيز نشان داده شده است.

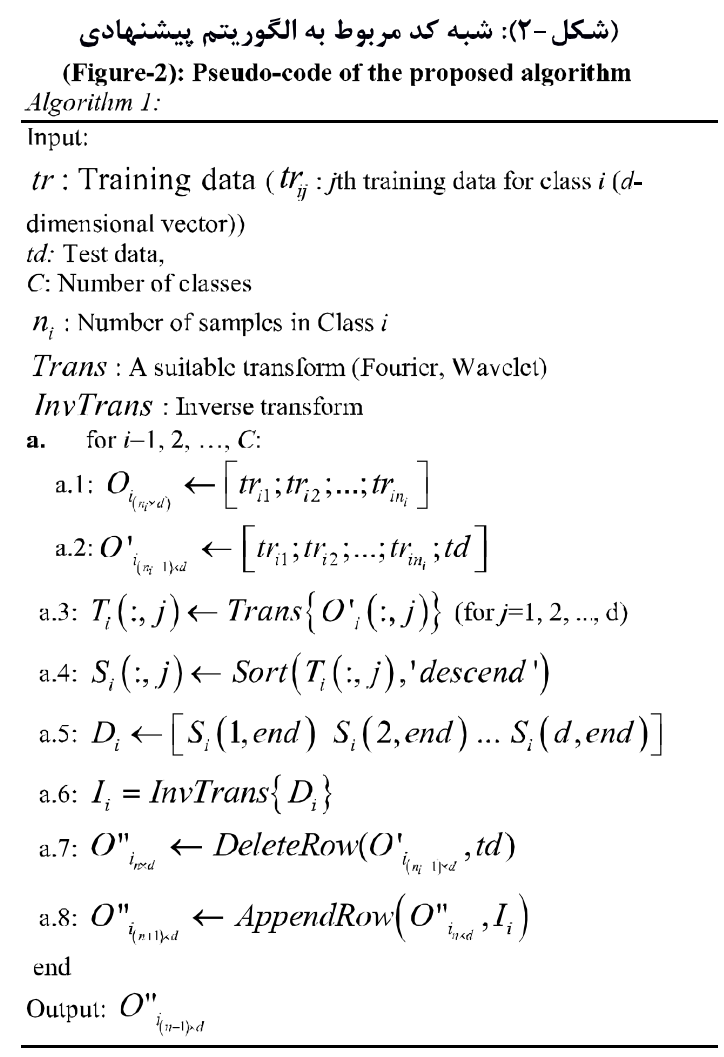

در بخش نتايج ييادهسازى، كارايى اين الكوريتم در كاربرد شناسايى جهره نشان داده است. در آن بخش، با انجام
ب-1- روى هر بعد (هر ستون) ماتريس داده، بdصورت

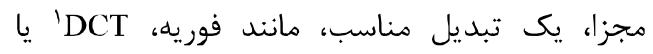

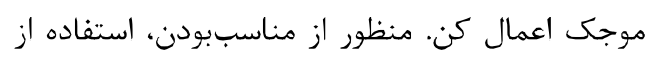

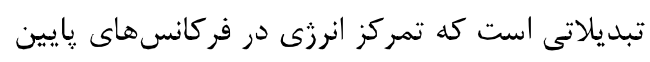

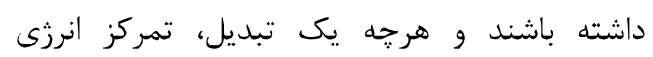

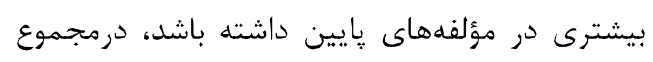

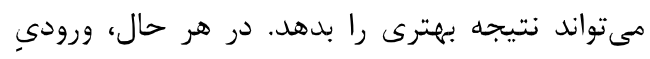

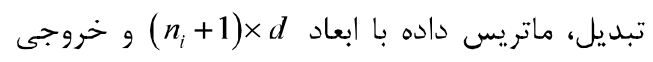

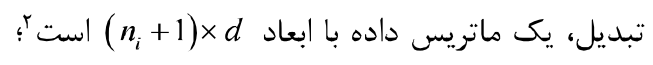
در اين رابطه، است.

ب-r- در هر ستون، مقادير ماتريس داده جديد (تبديل يافته)، را بلهترتيب نزولى مرتب كن.

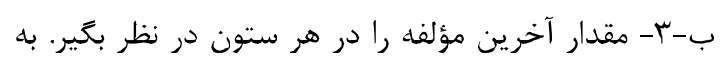
اين ترتيب، يك بردار d عنصرى از اين مقادير تشكيل مىشود. ب-F- واضح است كه بردار d بُعدى بلهدست آمده در قسمت

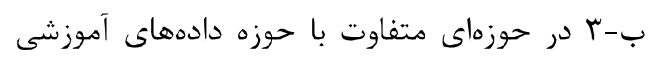

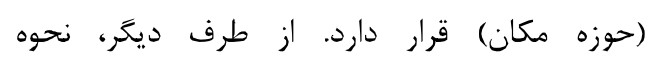

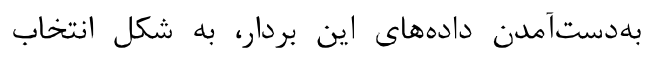

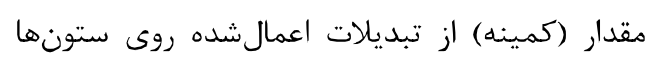

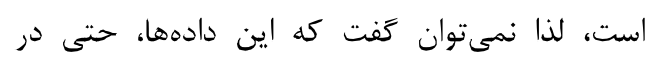
فضاى تبديل يافته (براى مثال فوريه) قرار دارند. به ايه ائ دانه هر حال، واضح است كه مىبايست در اين مرحله،

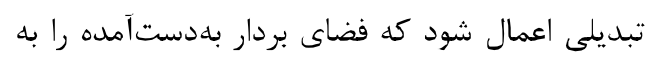

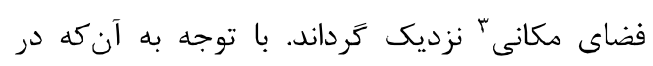

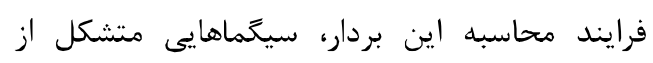

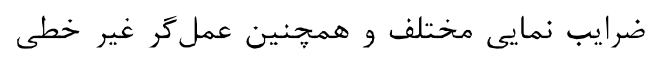
كمينهسازى مورد استفاده قرار ترفته است، درعمل،

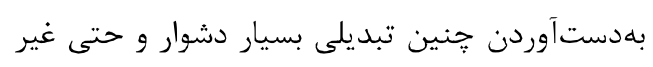

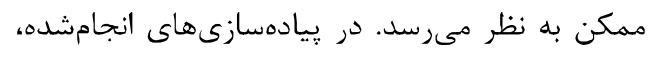
در اين مرحله، يك تبديل معكوس مورد استفاده قرار

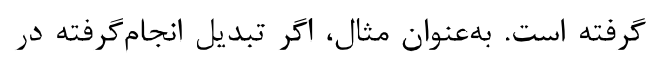

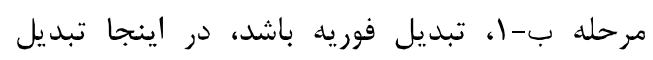
معكوس فوريه روى بردار d بُعدى، انجام گرفته است.

${ }^{1}$ Discrete cosine transform (DCT)

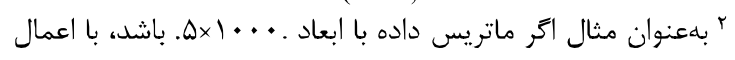

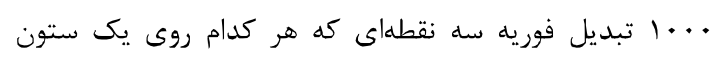

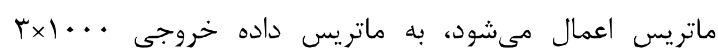

${ }^{3}$ Spatial

$$
\text { مىرسيم. }
$$


زيرا در آنها با اعداد غير صفر مواجه هستيم. اكر از

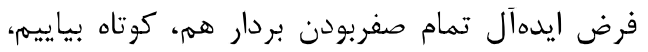

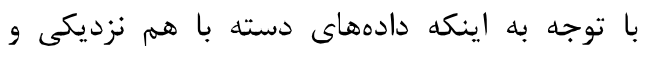

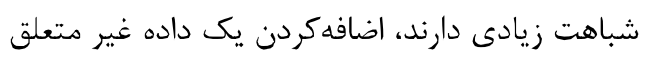
به دسته، اثر تخريبى خود را بر جاى مى تخذارد.

r-r- استفاده از الكوريتم ارائهشده در شناسايى جهره

در الكوريتم يادشده در قسمت قبل، هيجَّونه قيد و شرطى إسى درخصوص نحوه استخراج ويزگى و يا فرايند دستهبندى،

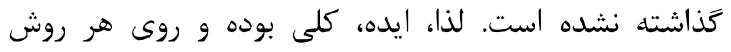

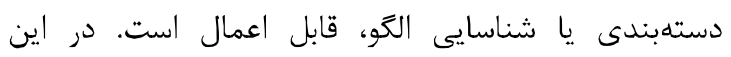

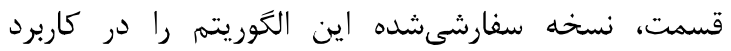
شناسايى جهره، بيان مى كنيه.

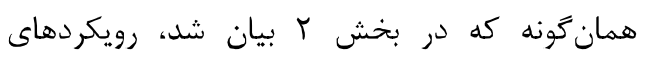
مبتنى بر CNN، در حوزههاى مربوط به شناسايى الكو، دقتهاى بسيار مطلوب دارند. همجنين، در همان بخش درون بيان

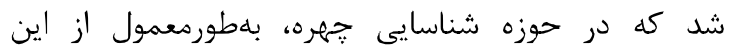

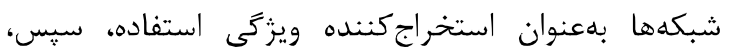
ويزگى هاى بهدستآمده، براى شناسايى به يك دستهابند داده

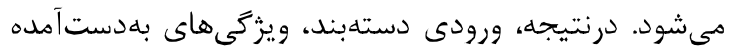

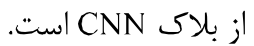
الكَوريتم يادشده در بخش ب-r با با توجه به نكات زير

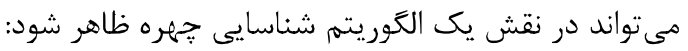

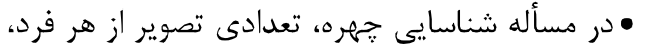
در اختيار داريم. اين مجموعه تصاوير، دراصطلاح كالرى ناميده مىشود. •در يك الكوريتم شناسايى جهره، افراد موجود درد درد كالرى، نقش دستهها را ايفا مىكنند. اخر تعداد

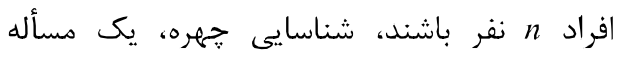
دستهبندى n دستهاى است.

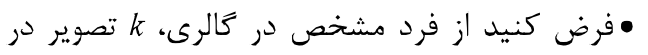

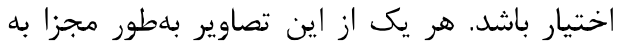

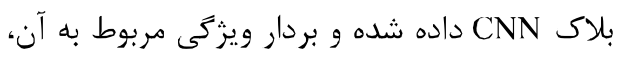

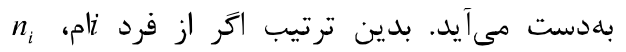

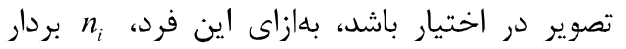

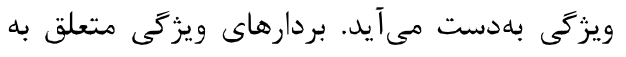
تصاوير افراد داخل كالرى، دجموعه داده آموزشى بردي

$$
\text { تشكيل مى دهند. }
$$

آزمايشهاى متعدد نشان دادهايم كه بهكاركيرى ويزگى هاى

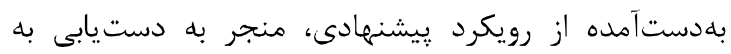
كارايى بهتر شده است.

r-r-r-r- توضيحاتى درخصوص مراحل الكوريتم

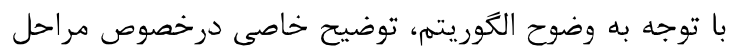

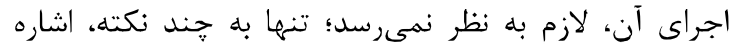

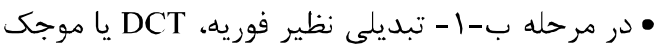
روى داده، اعمال شده است. نوع تبديل و اندازه

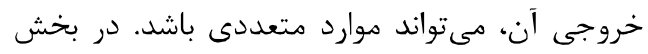

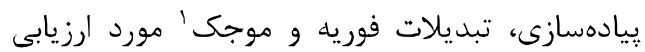
قرار كرفته است.

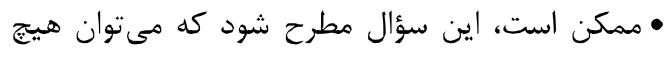

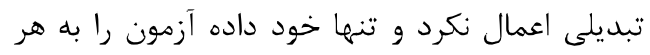

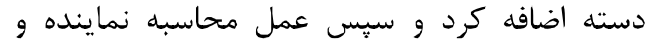

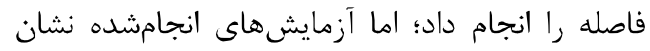

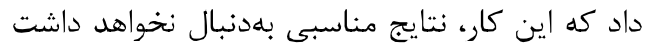

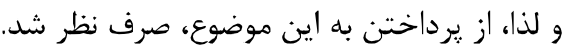

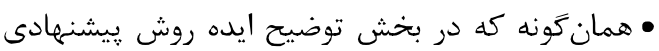

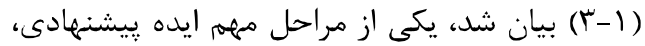

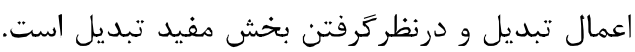
در اين قسمت، منظور از مفيدبودن را توضيح

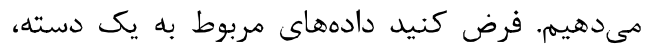

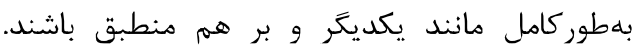

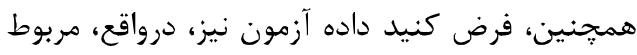

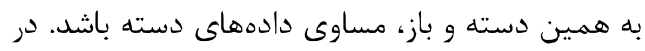

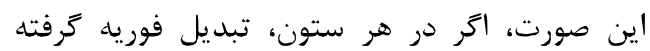

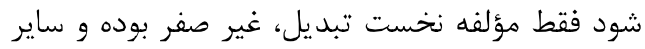

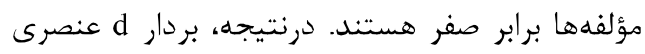

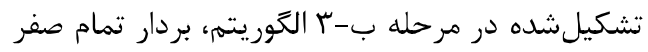

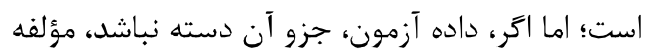

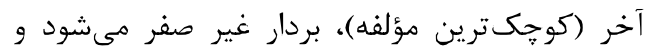

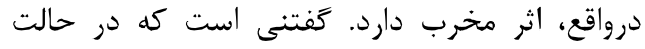
تعلق داده آزمون به دسته صحيح (تمام صفربودن دابن

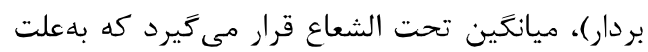

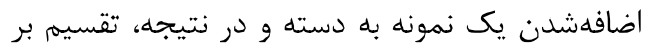

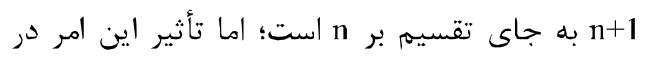
دسته واقعى بلمراتب، كمتر از دستههاى ديخر است؛

1 Wavelet 
خروجى: k (شماره دستهاى (فردى) كه منجر به ايجاد فاصله مينيمم شده است). در ادامه اين بخش، نخست، توصيف شرايط آزمايش (شامل مجموعه داده، سخت افزار و نرم افزار بهكار رفته) انجام مىشود. در ادامه، معيارهاى ارزيابى كارايى يك مئ الكوريتم شناسايى جهره بيان شده و در انتها، با بيان نتايج آزمايشهاى متعدد، نشان مىدهيم بهاربردن رويكرد ييشنهادى به عنوان استخراج ويزگگى، منجر به بهبود مناسبى در كارايى شناسايى جهره خواهد شد.

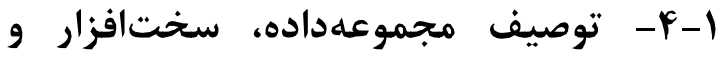 نرمافزار}

در جدول (f))، ff مجموعهدادة مورد استفاده، توضيح داده شداند. همجنين، در شكلهاى (r وfl) تصاوير مربوط به بعضى از آنها، نشان داده شده است. در جدول (ه) نيز، مشخصات سختافزار و همجنين ابزارهاى نرمافزارى مورد استفاده در پيادهسازىها، آورده

شده است.

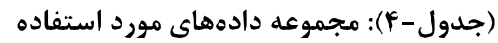

(Table-4): Datasets used in the paper

\begin{tabular}{|c|c|}
\hline توضيحات & نام \\
\hline 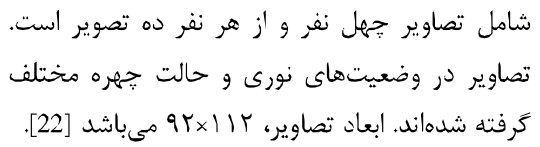 & AT\&T \\
\hline 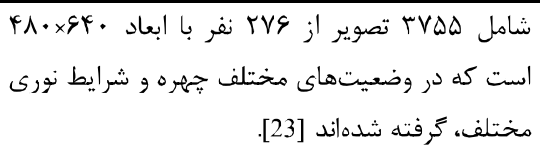 & MUCT \\
\hline 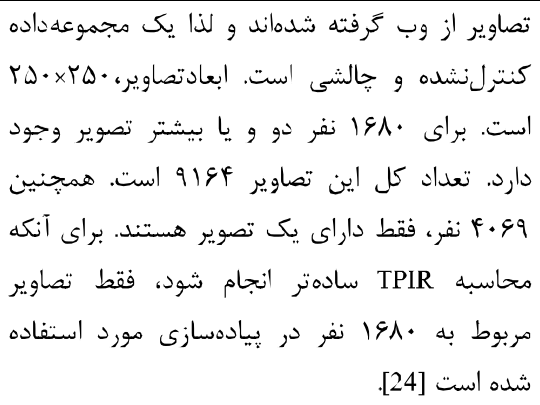 & LFW \\
\hline 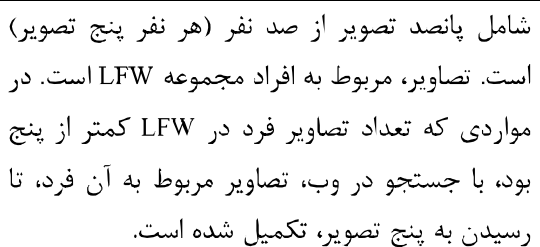 & 100LFW \\
\hline
\end{tabular}

•يك الخوريتم شناسايى جهره مىبايست در مواجهه با يكى تصوير مجهول، تعيين كند كه اين تصوير متعلق به جه فردى در كالرى است. در رويكردهاى تصوين

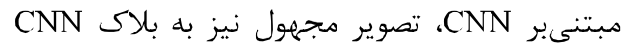

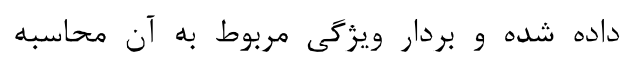

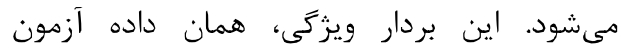
الخَوريتم ارائهشده ما، است.

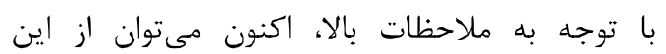

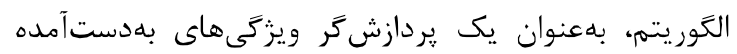
باوسيل؛ CNN، جهت شناسايى جهره استفاده كرد.

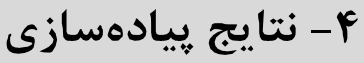

در اين بخش، كارايى رويكرد بيشنهادى براى استخراج

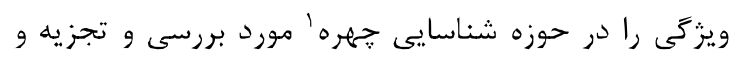

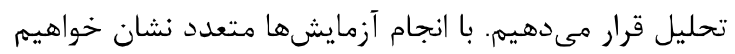
داد، ويزگگى هاى بهدست آمده توسط الخوريتم يادشده، منجر

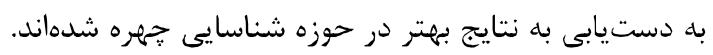

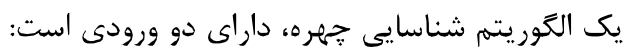
ل يك كالرى، شامل تصاوير تعدادى از افراد مشخص.

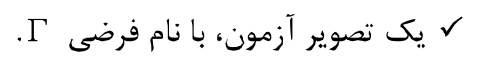

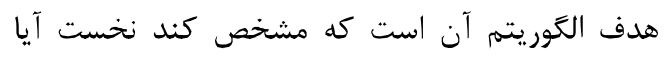
اين تصوير متعلق به فردى داخل كالرى است يا خير.

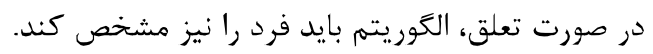

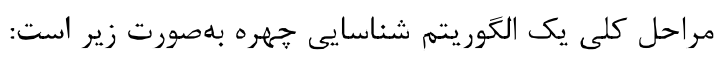

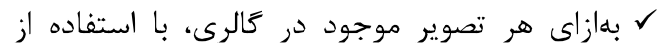
يك روش استخراج ويثزَى، يكى بردار ويثز بdدست بياور.

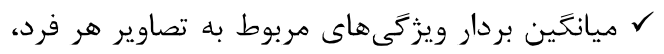
را محاسبه كن. فرض كنيد بهازاى فرد شماره ميانخين، برابر

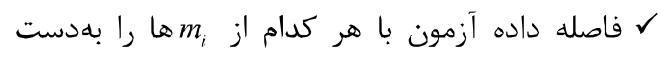
بياور.

$$
D_{i}=\operatorname{dist}\left(\Gamma, m_{i}\right)
$$

ل آر Di

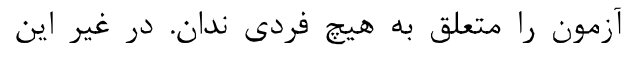
صورت، تصوير را به دستهاى (فردى) كه كمترين

$$
\text { ا موجب شده منسوب كن. } D_{i}
$$

$k=\arg _{i} \min D_{i}$

${ }^{1}$ Face recognition

سال Pa 
در اين رابطه، T، تعداد كل تصاوير غير متعلق بـ

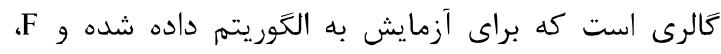

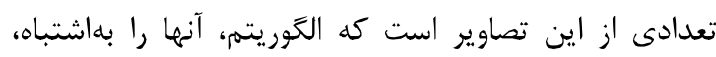
متعلق به كالرى دانسته است. يارامتر ح، مقدار آستانه قرار

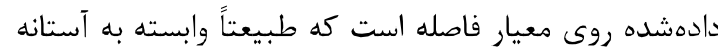
انتخابى $\tau$ است؛ همجنين، يارامتر TPIR نيز از رابطه زير بهدست ميى آيد: $\operatorname{TPIR}(R, \tau)=P(R, \tau) / S$

در اين رابطه S ، تعداد تصاوير متعلق به كالرى است

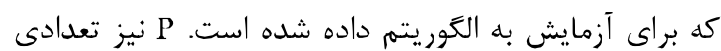

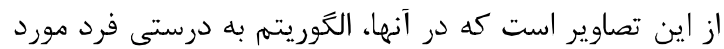
نظر را مشخص كرده است.

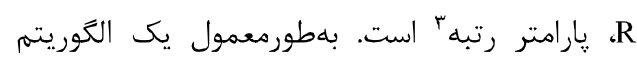
شناسايى קهره بلجاى يك نتيجه، R نامزد بلترتيب دقت تعلق، خروجى مي دهد. هر خه R بيشتر باشد، مقدار TPIR

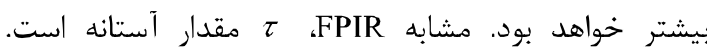
طبيعتاً، زمانى كه رتبه برابر يكى باشد، فقط يك فرد بهعنوان نتيجه شناسايى، اعلام مى شود. رئه

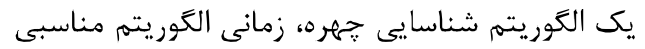

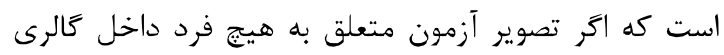
نباشد آن را اعلام كند و اخر تصوير، متعلق به فردى در كالرى باشد، بهدرستى آن فرد را تشخيص دهد. يارامتر FPIR دقت الگوريتم در تشخيص تعلق يا عدم تعلق تصاوير به كَالرى را مىسنجد و TPIR بيانگر ميزان كارايى الخوريتهم در تشخيص فرد صحيح است.

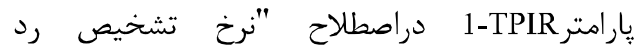

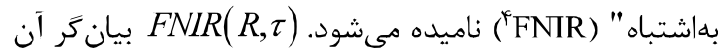
است كه از بين تصاوير آزمون كه درواقع متعلق به فردى در باميده داخل كَالرى هستند، الكوريتهم با جه نسبتى فرد مورد نظر را بهدرستى تشخيص نداده است. واضح است كه هر دو ياراهتر TPIR و FPIR در بازه [0,1] هستند. البته، براى اينكه يك الكوريتم شناسايى جهره عملكرد مناسبى داشته باشد، مي بايستى FPIR مقدار كم (نزديك به صفر) و TPIR، مقدار بزرى (نزديك به يك)

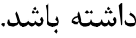

${ }^{3}$ Rank

${ }^{4}$ False negative identification rate (FNIR)
(جدول -ه): سختافزار و نرمافزار مورد استفاده

(Table-5): Hardware and software used in the paper

\begin{tabular}{|l|l|}
\hline \multicolumn{1}{|c|}{ نرم افزار } & \multicolumn{1}{|c|}{ سخت افزار } \\
\hline MATLAB 2017- & CPU: Corci7 (7700k)- RAM: 16GB- \\
MatConvNet ([25]) & Hard: (SSD-512GB)-Cachc: 8MB- \\
& GPU: 1070 (8 GB) \\
\hline
\end{tabular}

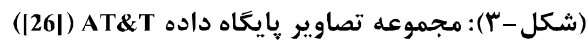

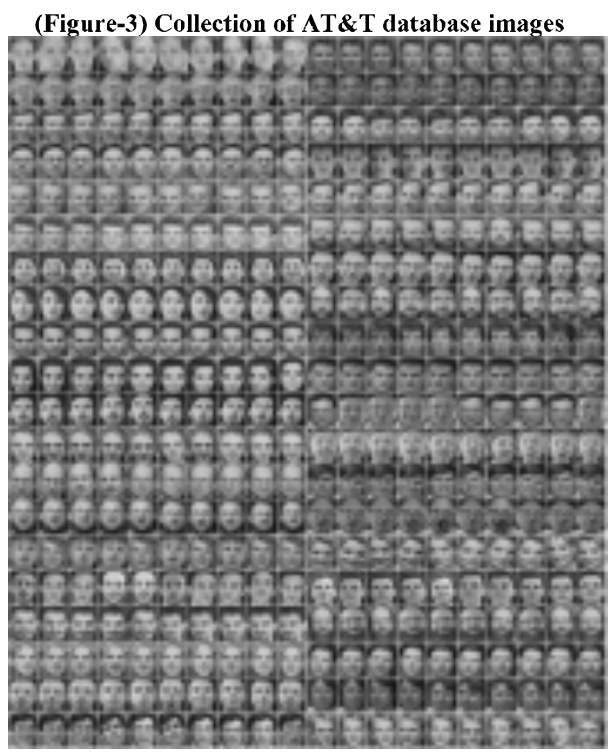

(شكل - (F) : بعضى تصاوير مجموعه داده LWW (جمع آورىشده توسط نويسندكان)

(Figure-4): Some of the LFW database images

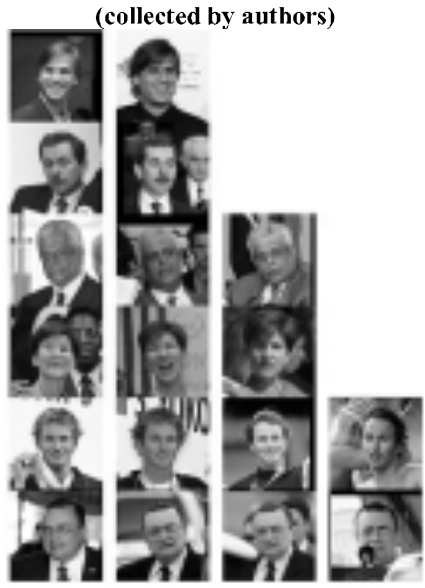

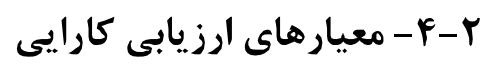

براى سنجش كارايى يك الكوريتهم شناسايى جهره، دو معيار

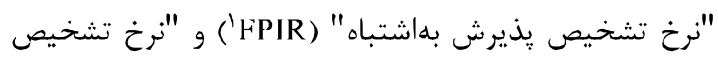

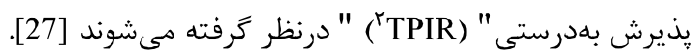
معيار FPIR بلهورت زير تعريف مىشود:

$\operatorname{FPIR}(\tau)=\frac{F(\tau)}{T}$

${ }^{1}$ False positive identification rate

${ }^{2}$ True positive identification rate 
فرض مى كند، تصاوير ورودى رنكى و با اندازه

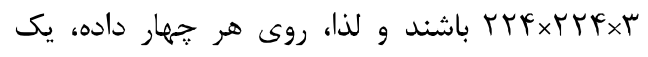

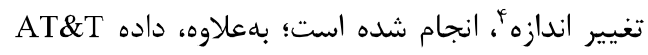

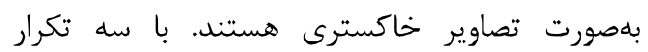

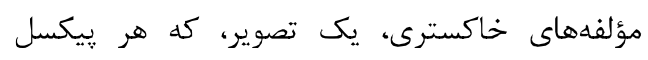

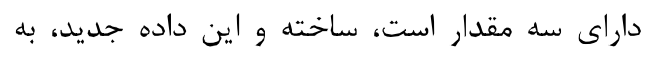
شبكه اعمال شد. در ادامه، نتايج يك سرى از شد آزمايشها و وريادهسازىها

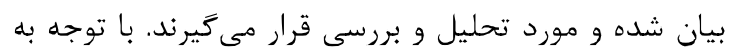

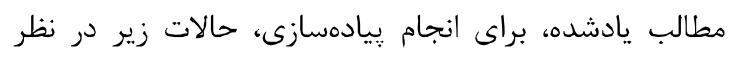

كرفته شده است:

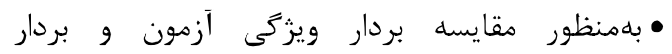

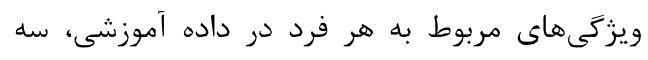

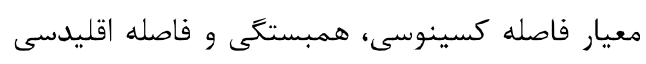
درنظر كرفته است.

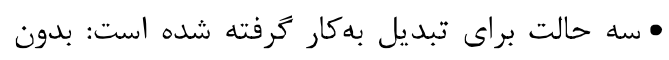

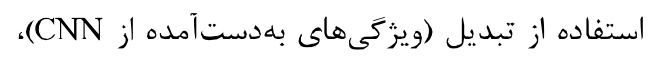

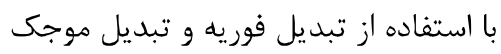

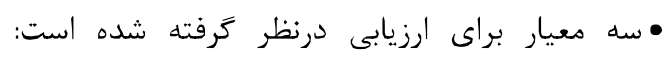

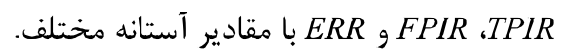
• جهار مجموعلداده براى ارزيابى بهكار برده شدانداند: 100LFW, LFW ،MUCT ،AT\&T بدينترتيب تعداد حالات بسيار زيادى براى بيادهسازى

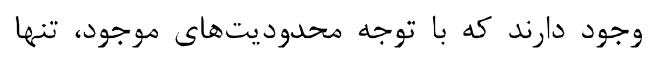

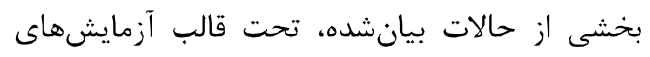

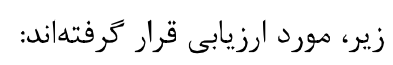
با توجه به آنكه، هدف، برورسى تأثير يسيردازي

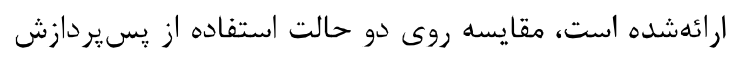

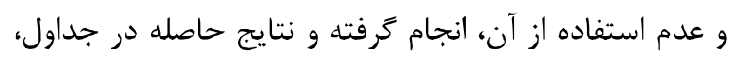
آورده شده است.

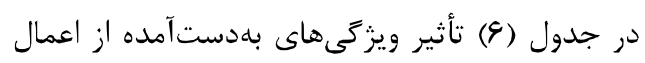

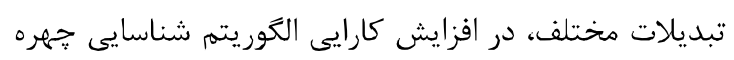
مبتنىبر شبكه VGGFace نشان داده شده است. بهكاركيرى داري

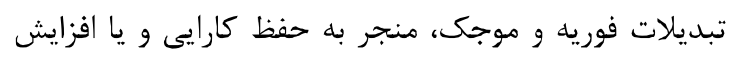

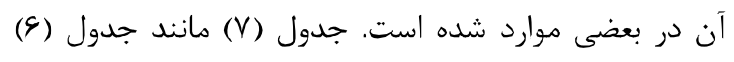

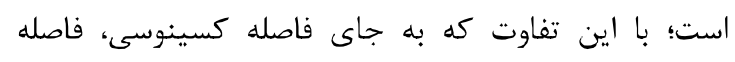

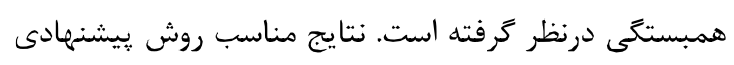

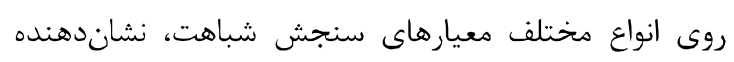

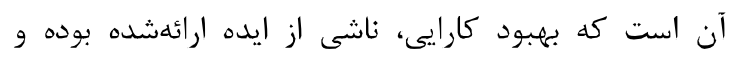

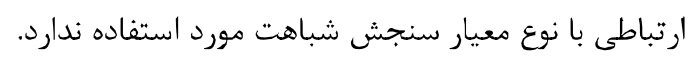

${ }^{4}$ Resizing
در يِادسازىهاى انجامشده، ميانگين وزندار

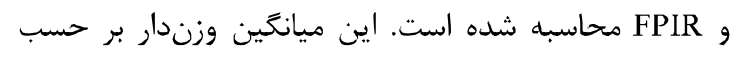

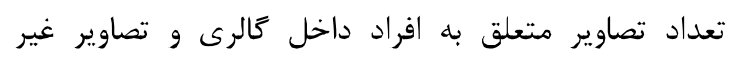

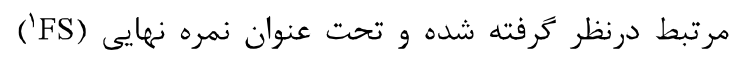

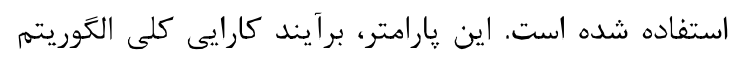

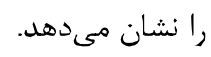

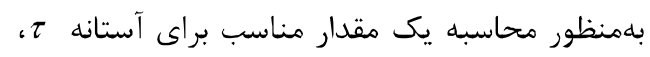

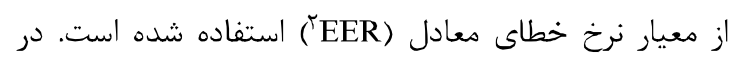

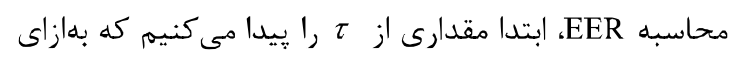

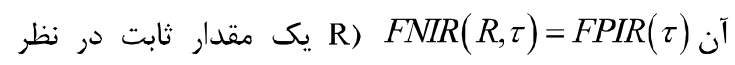

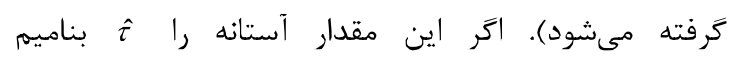

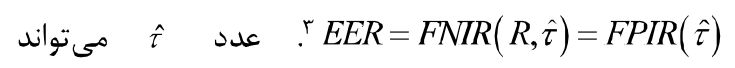
بلهنوان يك مقدار مناسب براى آستانه، محسوب شود.

\section{r-F- نتايج קيادهسازى، بررسى و تحليل}

در اين بخش به بيان، بررسى و تحليل نتايج الكوريته ارائه

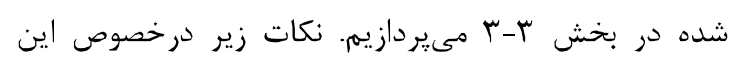

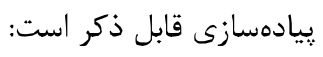

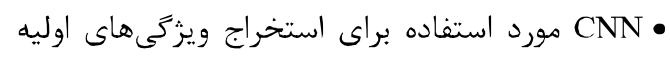

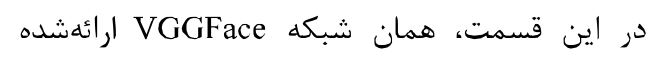

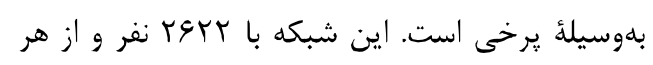

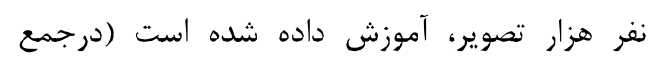

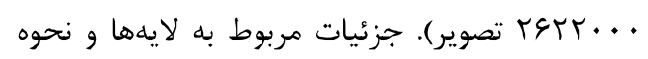
ساخت شبكه در [20] ارائه شده است.

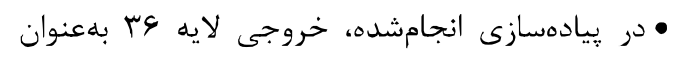

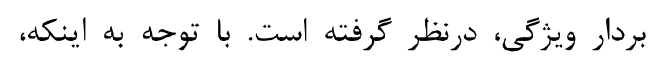

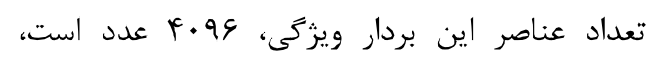

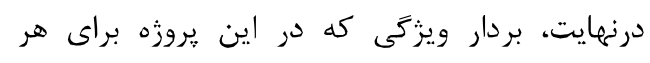

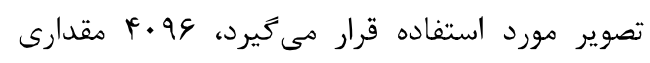

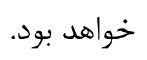
•ارزيابى كارايى با استفاده از هر دو معيار TPIR و و

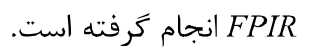

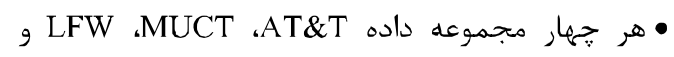
VGG- مورد ارزيابى قرار كرفتهاند. شبكه اده مونه

${ }^{1}$ Final score (FS)

${ }^{2}$ Equal error rate (ERR)

" درعمل، براى دادههاى واقعى، ممكن است هيجَّاه اين دو معيار،

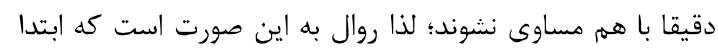

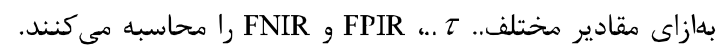

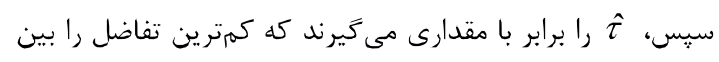
FNIR g FPIR 
بهمنظور نشاندادن كارايى الكوريتم در مواجهه با

روشهاى غير مبتنى بر شبكههاى عصبى، در جدول (11)

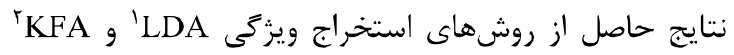

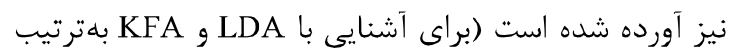

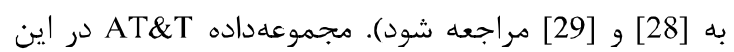

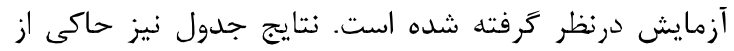

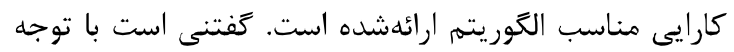
به دقت بسيار كم روشهاى سنتى روى دادئ دادهاى كنترل نشده، اين آزمايث روى ساير مجموعه دادهها، انجام نشده

در انتهاى اين بخش، درخصوص سربار محاسباتى

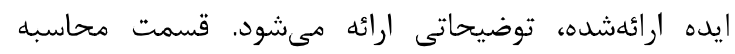

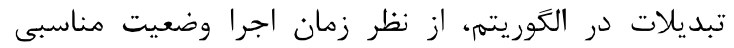

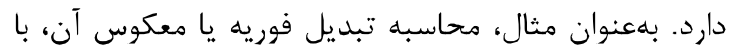

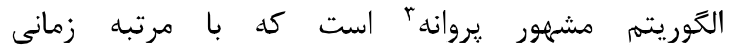
$N_{i}$ قابل انجام است. در رابطه يادشئ تعداد نقاط خروجى تبديل و d، أتعداد ويزگى ها هستتد. بقيه بخشهاى الكوريتم نيز شامل مواردى مانند مرتبسازى بعادي

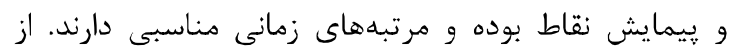

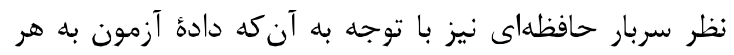

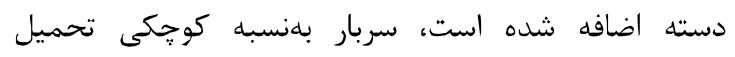

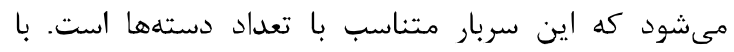
توجه به موارد بيانشده، ايده ييشنهادى، داراى سربار معقول و مناسبى است.

\section{ه- نتيجه كيرى}

در اين مقاله، روشى براى استخراج ويزگىهاى تصاوير جهره

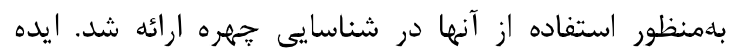

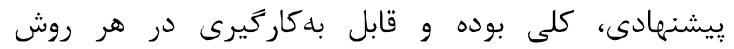
استخراج ويزگَى و هر الخوريتهم دستهبندى يا شناسايى الكو

در الكوريتم ارائهشده، داده آزمون به همه دستهماى موجود در كالرى، اضافه شده و تبديلى روى دادههاى هر ارئه دسته كه اكنون شامل داده آزمون نيز است، اعمال مى دكنيم.

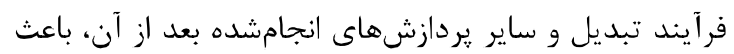

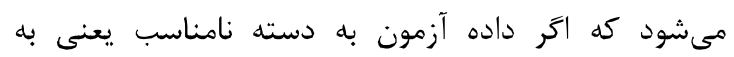

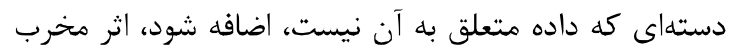
ايفا كرده و بدينترتيب، احتمال خطا (يعنى تشخيص

${ }^{1}$ Linear Discriminant $\Lambda$ nalysis (LDA)

${ }^{2}$ Kernel Fisher Analysis (KFA)

${ }^{3}$ Butterfly algorithm
ايده بيانشده منجر به بهببود وضعيت TPIR و يا به بيان معادل FNIR شده است. در مقابل، FPIR رويكرد ارائهشه در بعضى موارد، وضعيت نامناسبترى نسبت به حالت بدون تبديل دارد. بدينترتيب بهكارگيرى الكوريتم

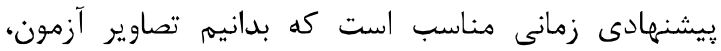
متعلق به كالرى هستند و الكوريتم فقط مى خواهد فردى را كه تصاوير متعلق به او است، در كالرى بيابد. در شكلهاى (ه و 9)، نمودار FPIR و FNIR بهازاى

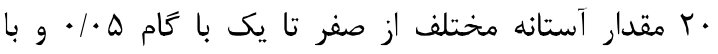
فرض استفاده از فاصلههاى همبستخى و اقليدسى، رسم شده است. داده 100LFW مورد استفاده قرار زرفته و با توجه به نمودارهاى رسمشده، يارامتر EER (محل تقاطع نمودارهاى

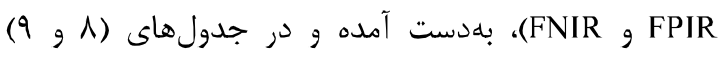
آورده شده است. جدول (·) (1) مشابه جدولهاى (ع و (ع) است؛ با اين تفاوت كه فاصله اقليدسى بهجاى فاصلههاى كسينوسى و همبستخى جايگزين شده است. باتوجه به آنكه از نظر تئورى، فاصله اقليدسى مىتواند هر مقدارى در بازه

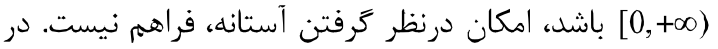
اين حالت، تصوير جرهره آزمون، به فردى در داخل كالرى منسوب مىشود كه كمترين فاصله را موجب شده به باشد. بهعلت عدم درنظرگرفتن مقدار آستانه، پارامتر FPIR قابل محاسبه نبوده و لذا در جدول، صرفا معيار TPIR آورده شده است. نتايج حاصل از اعمال فاصله اقليدسى نيز نشاندهنده كارايى بهتر رويكرد ارائهشده است. نكته قابل توجه، آن است كه نتايج ريادهسازى استى

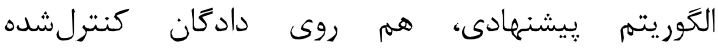
(آزمايشگاهى) مانند AT\&T و و هم روى مجموعه دادههاى واقعى (كنترلنشده و جمعآورىشده از وب) يعنى

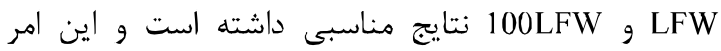
خود، مؤيدى بر كارابودن ايده ارائهشه است؛ بهخصوص

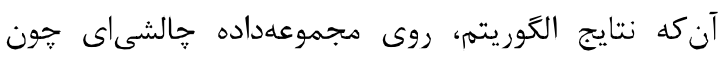

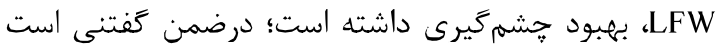

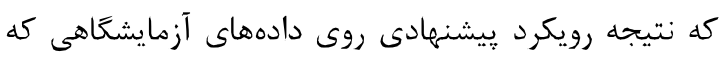
بدون اعمال روش نيز دقت بالايى دارند، بهطور كامل مناسب ردي ردي

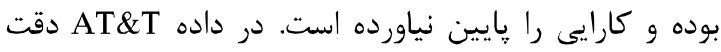

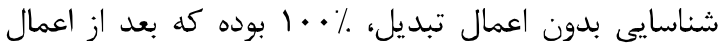

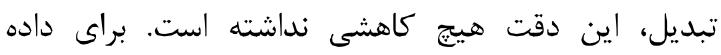

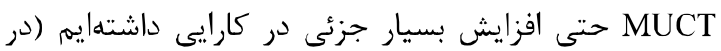
جدول · (1). (1) - (1) 
شبكه VGGFace كه يكى از قوىترين CNN در حوزه يردازش تصاوير جهره است، نشان داده شده است؛ بهلاوه، كارايى مناسب رويكرد ارائهشده، روى دادهاى جالشى (مانند LFW) و روى دارئ دادههاى آزمايشَاهى (مانند

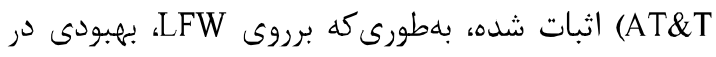

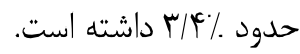

نادرست دسته) را كمتر مى كند؛ همجنين، افزودن داده

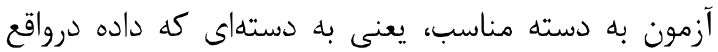
متعلق به آن است، اثر تخريبى كمترى دارد. در اعمال

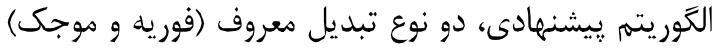

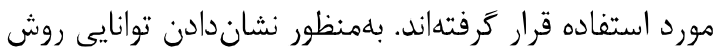
بيانشده، كارايى آن در بهبود ويزّكى هاى استخراجشده از

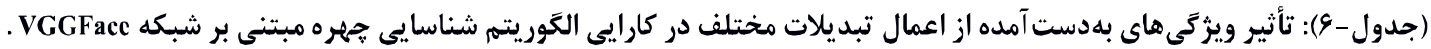

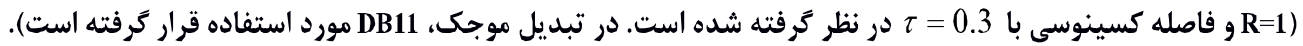

(Table -6): Effect of the features obtained from applying different transformations on the efficiency of the face recognition algorithm based on the VGGFace network ( $R=1$ and the cosine distance is considered by $\tau=0.3$. In the wavelet transform, the

\begin{tabular}{|c|c|c|c|}
\hline \multicolumn{4}{|c|}{ DB11 has been used.) } \\
\hline Final score & FPIR & TPIR & بدون تبديل \\
\hline 100 & 0 & 100 & AT\&T \\
\hline 99.74 & 2 & 99.97 & MUCT \\
\hline 86.52 & 8 & 86.22 & LFW \\
\hline 90.5 & 0 & 81 & $100 \mathrm{LFW}$ \\
\hline Final score & FPIR & TPIR & تبديل فوريه \\
\hline 100 & 0 & 100 & AT\&T \\
\hline 99.74 & 2 & 99.97 & MUCT \\
\hline 86.57 & 8 & 86.27 & LFW \\
\hline 90.5 & 0 & 81 & 100LFW \\
\hline Final score & FPIR & TPIR & تبديل موجك \\
\hline 100 & 0 & 100 & AT\&T \\
\hline 99.74 & 2 & 99.97 & MUCT \\
\hline 90.33 & 18 & 89.655 & LFW \\
\hline 91.1 & 0 & 82.2 & 100LFW \\
\hline
\end{tabular}

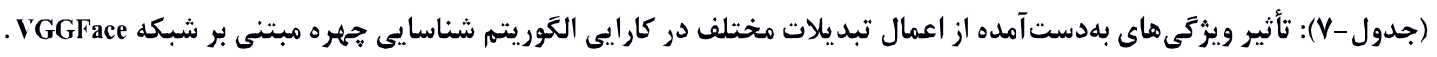

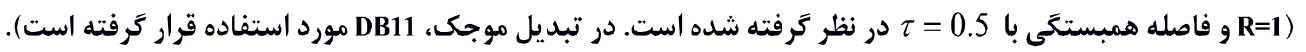

(Table -7): Effect of the features obtained from applying different transformations on the efficiency of the face recognition algorithm based on the VGGFace network ( $R=1$ and the correlation distance is considered by $\tau=0.5$.In the wavelet transform, the DB11 has

\begin{tabular}{|c|c|c|c|}
\hline \multicolumn{4}{|c|}{ been used.) } \\
\hline Final score & FPIR & TPIR & بدون تبديل \\
\hline 100 & 0 & 100 & AT\&T \\
\hline 99.62 & 3 & 99.97 & MUCT \\
\hline 87.28 & 17 & 87.52 & LFW \\
\hline 90.4 & 0 & 80.8 & 100LFW \\
\hline Final scorc & FPIR & TPIR & تبديل فوريه \\
\hline 100 & 0 & 100 & AT\&T \\
\hline 99.62 & 3 & 99.97 & MUCT \\
\hline 87.28 & 17 & 87.52 & LFW \\
\hline 90.4 & 0 & 80.8 & 100LFW \\
\hline Final score & FPIR & TPIR & تبديل موجك \\
\hline 100 & 0 & 100 & AT\&T \\
\hline 99.51 & 4 & 99.97 & MUCT \\
\hline 89.06 & 29 & 90.05 & LFW \\
\hline 91 & 0 & 82 & 100LFW \\
\hline
\end{tabular}



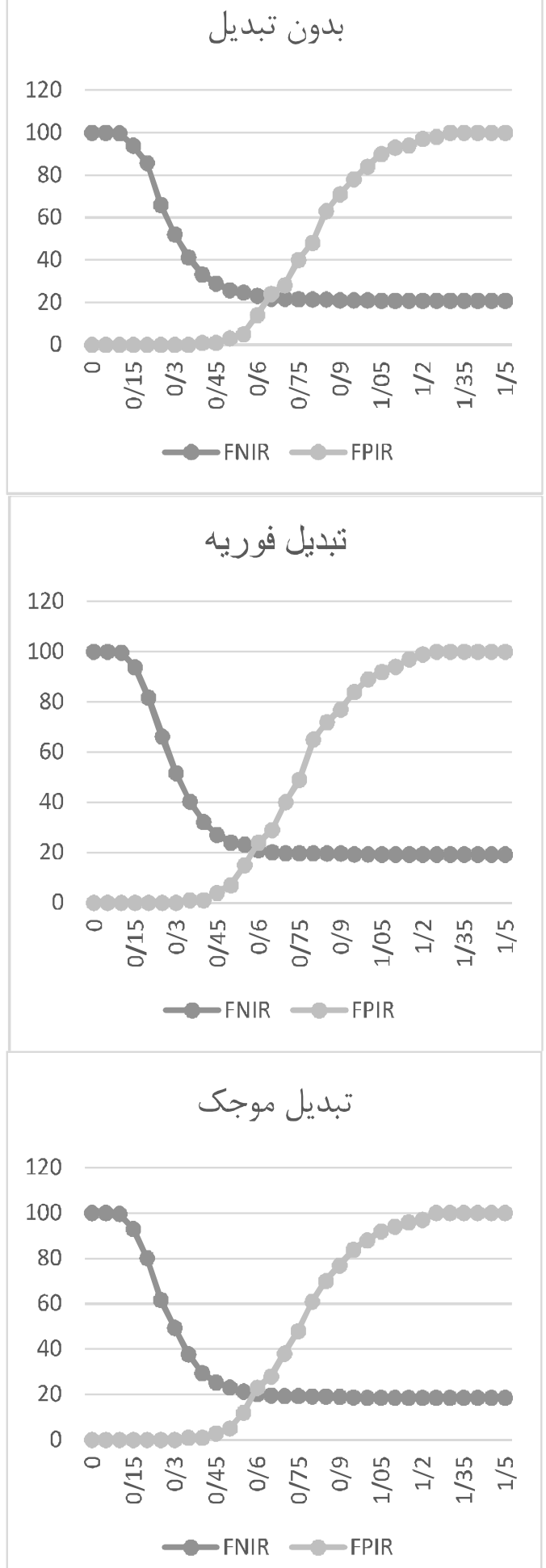

(شكل - FPIR و FNIR بهازاي بيست مقدار آستانه مختلف از صفر تا ه/ إبا كام هـ/• با فرض استفاده از فاصله اقليدسى

R=1 و داده 100LFW استفاده شده است).

(Figure-6): FPIR and FNIR for 20 different threshold values from zero to 1.5 with step 0.05 assuming the use of Euclidian distance ( $R=1$ and $100 \mathrm{LFW}$ is used.)

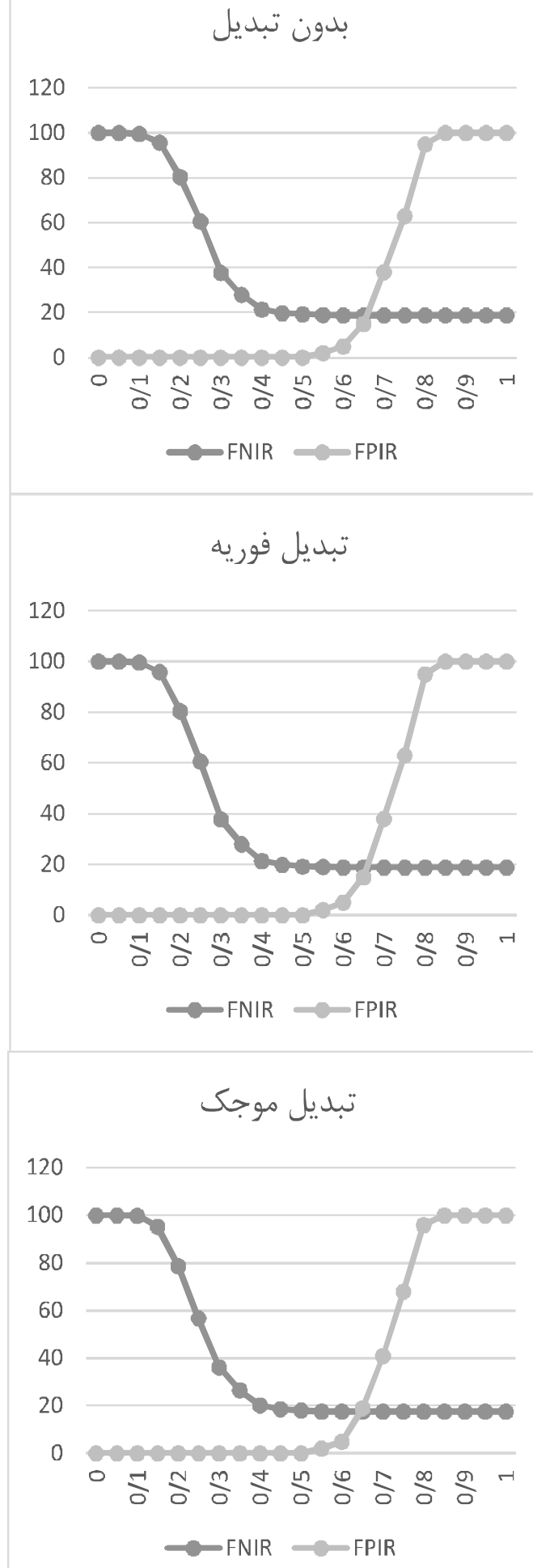

(شكل -ه): FPIR و FNIR بهازاي بيست مقدار آستانه مختلف

از صفر تا يك با كَام ه+|• با فرض استفاده از فاصله همبستكى

(R=1) و ماده 100LFW استفاده شده است).

(Figure-5): FPIR and FNIR for 20 different threshold values from zero to one with step 0.05 assuming the use of correlation distance ( $R=1$ and $100 \mathrm{LFW}$ is used.) 
(Table-11): Results of the proposed algorithm on features obtained from non-neural networks-based methods with different transformations. AT\&T dataset has been considered. $(R=1$, Euclidian distance and DB11 wavelet transform have been used)

\begin{tabular}{|c|c|c|c|}
\hline تبـيل موجـى & تبليل فوريه & بدون تبديل & روش \\
\hline 93.75 & 93.5 & 93.5 & LDA \\
\hline 97 & 97 & 96.25 & KFA \\
\hline
\end{tabular}

\section{6- References}

$$
\text { 9- مراجع }
$$

[1] A. Krizhevsky, I. Sutskever, and G. E. Hinton, "Imagenet classification with deep convolutional neural networks," in Advances in neural information processing systems, pp. 1097-1105, 2012.

[2] R. Brunelli and T. Poggio, "Face recognition: Features versus templates," IEEE transactions on pattern analysis and machine intelligence, vol. 15, no. 10, pp. 1042-1052, 1993.

[3] R. J. Baron, "Mechanism of human facial recognition," International Journal of Man Machine Studies, vol. 15, pp. 137-178, 1981.

[4] D .Ghimire, J. Lec, Z.-N. Li, and S. Jcong, "Recognition of facial expressions based on salient geometric features and support vector machines," Multimedia Tools and Applications, vol. 76, no. 6, pp. 7921-7946, 2017

[5] L. Wiskott, N. Krüger, N. Kuiger, and C. Von Der Malsburg, "Face recognition by elastic bunch graph matching," IEEE Transactions on pattern analysis and machine intelligence, vol. 19, no. 7, pp. 775-779, 1997.

[6] J. yves Bouguet, "Pyramidal implementation of the lucas kanade feature tracker," Intel Corporation, Microprocessor Research Labs, 2000.

[7] Y. Freund and R. E. Schapire, "A desiciontheoretic generalization of on-line learning and an application to boosting," in European conference on computational learning theory, 1995: Springer, pp. 23-37.

[8] G.-B. Huang, H. Zhou, X. Ding, and R. Zhang, "Extreme learning machine for regression and multiclass classification," IEEE Transactions on Systems, Man, and Cybernetics, Part B (Cybernetics), vol. 42, no. 2, pp. 513-529, 2012.

[9] W. Ouarda, H. Trichili, A. M. Alimi, and B. Solaiman, "Face recognition based on geometric features using Support Vector Machines," in Soft Computing and Pattern Recognition (SoCPaR), 2014 6th International Conference of, 2014: IEEE, pp. 89-95.

[10] M. A. Turk and A. P. Pentland, "Face recognition using eigenfaces," in Computer Vision and Pattern Recognition, 1991. Proceedings
(جدول -1): مقايسه كارايى الكوريتم ارائهشده با اعمال تبديلات

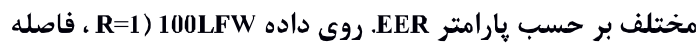
همبستكى و تبديل موجك DB11 مورد استفاده قرار كرفتلهاند).

(Table-8): Comparison of the efficiency of the proposed algorithm with different transformations according to the EER parameter over 100LFW data ( $R=1$, correlation distance and DB11 wavelet transform have been used).

\begin{tabular}{|c|c|c|c|}
\hline تبديل & تبدون & 100LFW \\
\hline تبديل & تبديل & \\
\hline 18.3 & 16.9 & 16.9 & EER \\
\hline
\end{tabular}

(جدول - 9): مقايسه كارايى الكوريتم ارائهشده با اعمال تبديلات

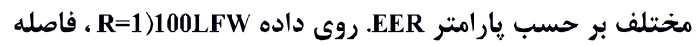
اقليدسى و تبديل موجك DB11 مورد استفاده قرار گرفتهاند).

(Table-9): Comparison of the efficiency of the proposed algorithm with different transformations according to the EER parameter over $100 L F W$ data $(R=1$, Euclidian distance and DB11 wavelet transform have been used)

\begin{tabular}{|c|c|c|c|}
\hline تبديل & تبديل & & \\
تبديل & 100LFW \\
\hline 21.6 & 22.5 & 22.9 & EER \\
\hline
\end{tabular}

(جدول -+1): تأثير ويزَّى هاى بهدست آمده از اعمال تبديلات

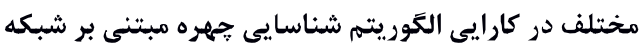

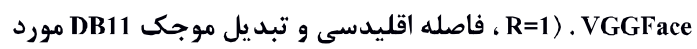

$$
\text { استفاده قرار كرفتهاند). }
$$

(Table-10): Effect of the features obtained from applying different transformations on the efficiency of the face recognition algorithm based on the VGGFace network $(R=1$, Euclidian distance and DB11 wavelet

\begin{tabular}{|c|c|}
\hline TPIR & تبديل فوريه \\
\hline 100 & AT\&T \\
\hline 99.95 & MUCT \\
\hline 91.02 & LFW \\
\hline 80.8 & 100LFW \\
\hline TPIR & تبديل موجك \\
\hline 100 & AT\&T \\
\hline 99.95 & MUCT \\
\hline 91.63 & LFW \\
\hline 81.4 & 100LFW \\
\hline TPIR & بدون تبديل \\
\hline 100 & AT\&T \\
\hline 99.92 & MUCT \\
\hline 87.19 & LFW \\
\hline 79.2 & 100LFW \\
\hline
\end{tabular}
transform have been used)

$$
\begin{aligned}
& \text { (جدول -1|): نتايج الكوريتم ارائهشده با فرض استفاده از }
\end{aligned}
$$

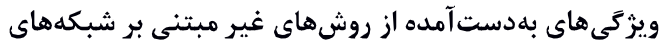

$$
\begin{aligned}
& \text { عصبى با اعمال تبديلات مختلف. داده درنظر كرفته شده، AT\&T }
\end{aligned}
$$

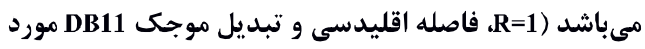

$$
\begin{aligned}
& \text { استفاده قرار كرفتهاند) }
\end{aligned}
$$


[22] F. S. Samaria and A .C. Harter, "Parameterisation of a stochastic model for human face identification," in Proceedings of 1994 IEEE workshop on applications of computer vision, 1994: IEEE, pp. 138-142.

[23] S. Milborrow, J. Morkel, and F. Nicolls, "The MUCT landmarked face database," Pattern Recognition Association of South Africa, vol. 201, no. 0, 2010.

[24] G. B. Huang, M. Mattar, T. Berg, and E. Learned-Miller, "Labeled faces in the wild: A database forstudying face recognition in unconstrained environments," in Workshop on faces in'Real-Life'Images: detection, alignment, and recognition, 2008.

[25] A. Vedaldi and K. Lenc, "Matconvnet: Convolutional neural networks for matlab," in Proceedings of the 23rd ACM international conference on Multimedia, 2015: ACM, pp. 689-692.

[26] GTDLBench. The Database of Faces (AT\&T) [Online]. Available: https://gitdisl.github.io/GTDLBench/datascts/att_face_dat aset/.

[27] P. Grother and M. Ngan, "Performance of face identification algorithms," NIST Inter-agency Internal Report8009, 2014.

[28] R. A. Fisher, "The use of multiple measurements in taxonomic problems," Annals of eugenics, vol. 7, no. 2, pp. 179-188, 1936.

[29] S. Mika, G. Ratsch, J. Weston, B. Scholkopf, and K.-R. Mullers, "Fisher discriminant analysis with kernels," in Neural networks for signal processing IX: Proceedings of the 1999 IEEE signal processing society workshop (cat. no. 98th8468), 1999: Ieee, pp. 41-48.

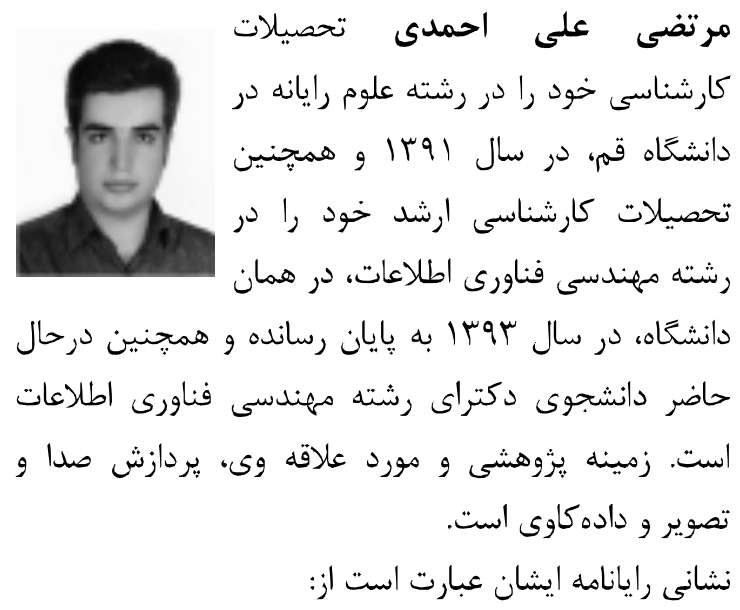

ma.ahmadi@qom.ac.ir
CVPR'91., IEEE Computer Society Conference on, 1991: IEEE, pp. 586-591.

[11] H. Hotelling, "Analysis of a complex of statistical variables into principal components," Journal of educational psychology, vol. 24, no. 6, p. 417, 1933

[12] P. N. Belhumeur, J. P. Hespanha, and D. J. Kriegman, "Eigenfaces vs. fisherfaces: Recognition using class specific linear projection," IEEE Transactions on pattern analysis and machine intelligence, vol. 19, no. 7, pp. 711-720, 1997.

[13] J. Wright, A. Y. Yang, A. Ganesh, S. S. Sastry, and Y. Ma, "Robust face recognition via sparse representation," IEEE transactions on pattern analysis and machine intelligence, vol. 31, no. 2, pp. 210-227, 2009.

[14] A. Wagner, J. Wright, A. Ganesh, Z. Zhou, H. Mobahi, and Y. Ma, "Toward a practical face recognition system: Robust alignment and illumination by sparse representation," IEEE Transactions on Pattern Analysis and Machine Intelligence, vol. 34, no. 2, pp. 372-386, 2012.

[15] Y. Sun, X. Wang, and X. Tang, "Deep learning face representation from predicting 10,000 classes," in Proceedings of the IEEE Conference on Computer Vision and Pattern Recognition, 2014, pp. 1891-1898.

[16] Y. Sun, Y. Chen, X. Wang, and X. Tang, "Deep learning face representation by joint identification-verification," in Advances in neural information processing systems, 2014, pp. 1988-1996.

[17] Y. Sun, X. Wang, and X. Tang, "Deeply learned face representations are sparse, selective, and robust," in Proceedings of the IEEE conference on computer vision and pattern recognition, 2015 , pp. 2892-2900.

[18] Y. Sun, D. Liang, X. Wang, and X. Tang, "Decpid3: Face recognition with very deep neural networks," arXiv preprint arXiv:1502.00873, 2015.

[19] Y. Taigman, M. Yang, M. A. Ranzato, and L. Wolf, "Deepface: Closing the gap to humanlevel performance in face verification," in Proceedings of the IEEE conference on computer vision and pattern recognition, 2014, pp. 1701-1708.

[20] O. M. Parkhi, A. Vedaldi, and A. Zisserman, "Deep Face Recognition," in $B M V C, 2015$, vol. 1, no. 3, p. 6 .

[21] K. Simonyan and A. Zisserman, "Very deep convolutional networks for large-scale image recognition," arXiv preprint arXiv:1409.1556, 2014. 

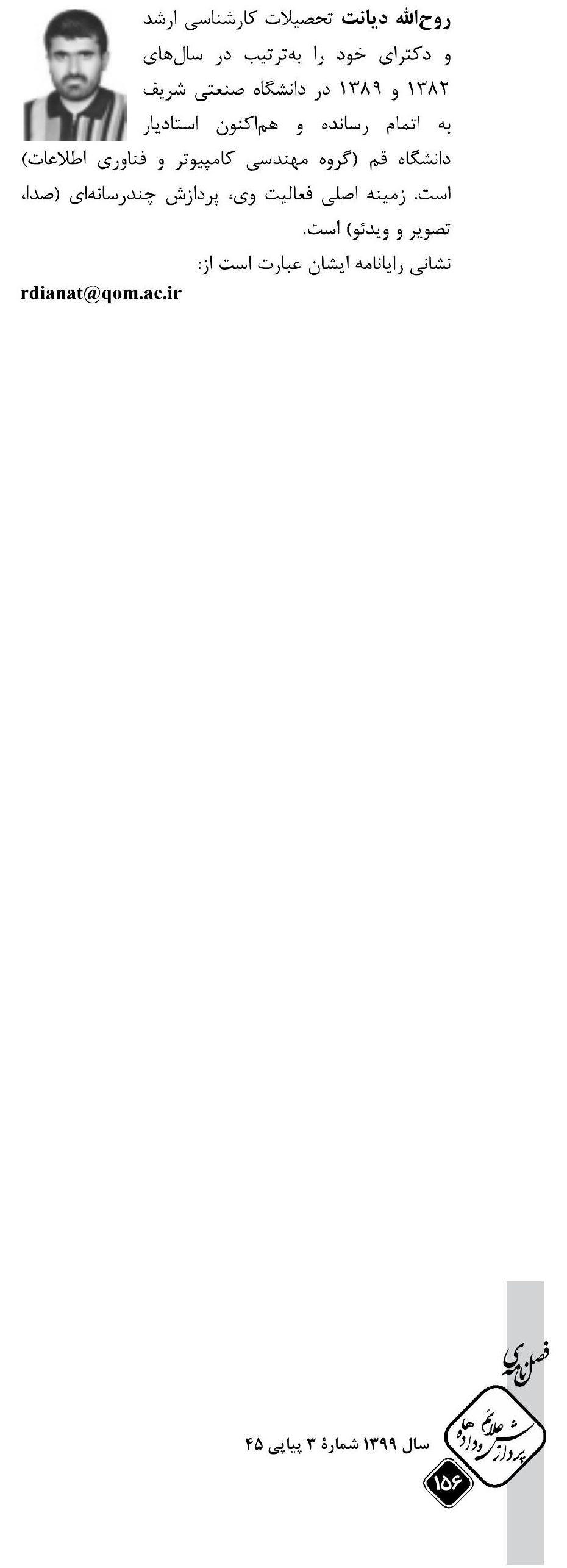